Illinois State University

ISU ReD: Research and eData

Theses and Dissertations

$6-27-2018$

\title{
Chamaecrista Fasciculata In Tallgrass And Sand Prairies: The Potential For Differential Responses
}

Robert W. Philips

Illinois State University, rwphili@ilstu.edu

Follow this and additional works at: https://ir.library.illinoisstate.edu/etd

Part of the Botany Commons, and the Evolution Commons

\section{Recommended Citation}

Philips, Robert W., "Chamaecrista Fasciculata In Tallgrass And Sand Prairies: The Potential For Differential Responses" (2018). Theses and Dissertations. 918.

https://ir.library.illinoisstate.edu/etd/918

This Thesis is brought to you for free and open access by ISU ReD: Research and eData. It has been accepted for inclusion in Theses and Dissertations by an authorized administrator of ISU ReD: Research and eData. For more information, please contact ISUReD@ilstu.edu. 


\section{ROBERT W. PHILIPS}

\section{Pages}

Successful establishment of a diversity of native species has become an important goal for restoration site managers to achieve, however as seed sources for a species may occur in habitats with different abiotic and biotic characteristics. Consequently, seeds from different sources may vary in their success in a restoration. Chamaecrista fasciculata, a native prairie species, occurs in two divergent prairie types - tallgrass and sand prairies. Tallgrass prairies have a moist soil with dense vegetation; in contrast, sand prairies have a well-drained sandy soil with sparse vegetation. I propose differential selection acting on populations in these prairie types would affect their seeds success in restorations. Given the denser vegetation of the tallgrass prairies, plants must be capable of competing for light resources, thus I predict the plants from tallgrass seed sources have a better competitor tolerance and would be more successful in a reconstructed tallgrass prairie. To assess the effect of sand vs. tallgrass prairie seed sources, I conducted a greenhouse and a common garden study. In the greenhouse study, all plants from the three tallgrass and three sand prairies were reduced in height, biomass, and fruit production when exposed to a competitor (Schizachyrium scoparium). Further, sand prairie plants had greater fruit production while tallgrass prairie plants flowered and senesced earlier. In the common garden study, plants within the no trim treatment had a greater relative leaf area lost to herbivory in late seasonal measurements. However, my results found no evidence of tallgrass seed sources showing any greater competitive tolerance or relative success in comparison to sand prairie seed sources in the greenhouse and common garden studies. Still, different prairie types were found to differ in some observed traits in a greenhouse setting. Further study is necessary to determine if the observed differences in the greenhouse and the native prairies would impact restorations. 
ROBERT W. PHILIPS

\author{
A Thesis Submitted in Partial \\ Fulfillment of the Requirements \\ for the Degree of \\ MASTER OF SCIENCE \\ School of Biological Sciences \\ ILLINOIS STATE UNIVERSITY
}


Copyright 2018 Robert W. Philips 
CHAMAECRISTA FASCICULATA IN TALLGRASS AND SAND PRAIRIES: THE POTENTIAL FOR DIFFERENTIAL RESPONSES

ROBERT W. PHILIPS

COMMITTEE MEMBERS:

Diane Byers, Chair

Victoria Borowicz

Benjamin Sadd 


\section{ACKNOWLEDGMENTS}

I would like to thank Diane Byers, Vickie Borowicz, and Ben Sadd for their assistance with my research and being a part of my committee. Further, I would like to thank Joe Oremus and Victoria DeMichel for their help in both the common garden and greenhouse studies and Phi Sigma and Illinois State University for funding. Finally, I would like to thank the Illinois Department of Natural Resources for allowing me to collect seeds from their sites, John Franklin for allowing me to perform a common garden study on his property, and Tim Lindenbaum for providing historical information about the sites restoration methods and previous land uses.

R. W. P. 


\section{CONTENTS}

Page

ACKNOWLEDGMENTS

TABLES iv

FIGURES

CHAPTER I: IS THERE A DIFFERENCE IN THE COMPETITIVE RESPONSE OF

CHAMAECRISTA FASCICULATA FROM SAND VS. TALLGRASS PRAIRIES? 1

$\begin{array}{ll}\text { Introduction } & 1\end{array}$

Methods $\quad 5$

$\begin{array}{ll}\text { Study Species } & 5\end{array}$

$\begin{array}{ll}\text { Prairie Seed Sources } & 6\end{array}$

$\begin{array}{ll}\text { Experimental Design } & 7\end{array}$

$\begin{array}{lr}\text { Plant Assessment } & 8\end{array}$

$\begin{array}{ll}\text { Statistical Analyses } & 9\end{array}$

$\begin{array}{ll}\text { Results } & 10\end{array}$

$\begin{array}{ll}\text { Discussion } & 12\end{array}$

$\begin{array}{ll}\text { References } & 16\end{array}$

$\begin{array}{ll}\text { Tables } & 25\end{array}$

$\begin{array}{ll}\text { Figures } & 35\end{array}$

CHAPTER II: DOES SEED SOURCE OF CHAMAECRISTA FASCICULATA AFFECT ITS

SUCCESS IN A RESTORED TALLGRASS PRAIRIE 43

$\begin{array}{ll}\text { Introduction } & 43\end{array}$

Methods 48 
$\begin{array}{lr}\text { Study Species } & 48\end{array}$

$\begin{array}{ll}\text { Seed Source Population } & 49\end{array}$

$\begin{array}{lr}\text { Experimental Site } & 50\end{array}$

Experimental Design

Plant Assessment $\quad 52$

$\begin{array}{ll}\text { Arthropod Assessment } & 54\end{array}$

Statistical Analyses $\quad 55$

Results

$\begin{array}{ll}\text { Discussion } & 59\end{array}$

$\begin{array}{ll}\text { References } & 62\end{array}$

$\begin{array}{ll}\text { Tables } & 69\end{array}$

$\begin{array}{ll}\text { Figures } & 74\end{array}$

APPENDIX A: FIELD SITE SEED COLLECTION INFORMATION 80

APPENDIX B: SPECIES COMPOSITION IN FIELD SITE SAMPLE PLOTS 83

APPENDIX C: ARTHROPOD SURVEY INFORMATION 89 


\section{TABLES}

Table

Page

1. Prairie Soil Characteristics

2. Natural Prairie Vegetation Data

3. Repeated Measures Height Analysis

4. Profile Analysis for Height

5. Aboveground Biomass Nested ANOVA

6. Fruit Biomass Nested ANOVA

7. Fruit Production Nested Factorial ANOVA

8. Developmental Nested Factorial MANOVA

9. Growth Rate Split-Plot MANOVA Analysis

10. Biomass Split-Plot MANOVA Analysis

11. Nectar Production Split-Plot ANOVA Analysis

12. Relative Leaf Area Lost to Herbivory, Measurement 1, Split- Plot ANOVA Analysis 72

13. Relative Leaf Area Lost to Herbivory, Measurement 2, Split- Plot ANOVA Analysis 73 


\section{FIGURES}

Figure

1. Mean Height

2. Biomass Production by Competition Treatment 36

3. Fruit Production by Competition Treatment 37

4. Fruit Production by Prairie Type 38

5. Days to Flowering and Senescence by Treatment 39

6. Height at Flowering Day and Senescence by Treatment 40

7. Height at Flowering Day and Senescence by Prairie Type 41

8. Days to Flowering and Senescence by Prairie Type 42

9. $\quad$ Field Study Mean Height $\quad 74$

$\begin{array}{ll}\text { 10. Field Aboveground Biomass } & 75\end{array}$

$\begin{array}{ll}\text { 11. Field Fruit Biomass } & 76\end{array}$

12. Nectar Production $\quad 77$

$\begin{array}{ll}\text { 13. Relative Impact of Herbivory (July 24-25) } & 78\end{array}$

14. Relative Impact of Herbivory (August 30-September 1) 79 


\section{CHAPTER I: IS THERE A DIFFERENCE IN THE COMPETITIVE RESPONSE OF}

CHAMAECRISTA FASCICULATA FROM SAND VS. TALLGRASS PRAIRIES?

\section{Introduction}

Species that occur across a wide geographic range are often present in multiple environmental types (Lindborg and Eriksson 2004; Lowry and Willis 2010). Differences in the characteristics of environments often lead to contrasting selection within species resulting in phenotypically and genetically distinct ecotypes within a species as found in the classic study by Clausen et al. (1948). This study and associated research were the first to use a reciprocal transplant approach to assess local adaptation across an environmental gradient. One of their results showed that populations of Achillea which varied in height in their native populations when grown in a series of experimental elevation gardens, provided evidence that the variation among population for height must be at least partly genetic (Clausen et al. 1948). Further, in a study conducted by Lowry and Willis (2010), populations of Mimulus guttatus found in contrasting habitat types were found to differ in their life histories. Specifically, populations found in moist coastal habitats were perennials while populations found in dry inland habitats were annuals (Lowry and Willis 2010). These ecotypes are better suited to a certain environment than other populations of the same species, which may be suited to another habitat (Clausen et al. 1948; Lowry and Willis 2010).

Environments across a species range can vary in both abiotic factors (soil, temperature, moisture, seasonal climate patterns) and biotic factors (competitors, predators, mutualists) (Leimu and Fischer 2008). Populations located within different environments would be exposed to different biotic and abiotic selection pressures, and consequently traits of species would be 
expected to diverge in their responses depending on the specific environmental conditions. The response to this selection will be dependent on phenotypic and genetic diversity for the particular traits that can enable species to survive and reproduce in particular environmental conditions. If so, divergent selection can lead to populations with unique trait values (Endler 1986).

The potential for differential adaptation due to environmental variation has been documented in a diversity of plant species (Clausen et al. 1948; Johnson et al. 2010; Lowry and Willis 2010; Finney et al. 2016). Contrasting selection by environmental conditions can result in genetically distinct ecotypes that show greater fitness in a similar vs. alternative habitat. In reciprocal transplant studies, ecotypes have shown greater fitness and reproductive success in their native habitat versus the alternate habitat and exhibit different life history strategies (Lowry and Willis 2010). Further, ecotypes have shown to exhibit differential responses when placed in the same habit, where the local ecotype produces greater aboveground biomass (Finney et al. 2016) or has a more beneficial symbiotic relationship with soil microbes (Johnson et al. 2010). Prairie plants that are distributed across a large geographic range and can be subject to different selective pressures such as rainfall and soil type across a climatic gradient resulting in local ecotypes from drier regions that exhibit greater fitness in areas of low rainfall (Johnson et al. 2015) or lead to genetic divergence (Gray et al. 2014). In the tallgrass prairie region of Midwestern North America there are many different types of prairies. In Illinois the prairies are categorized into over ten types based on variation in glacial history, bedrock, soils, and the distribution of plants and animals (White and Madany 1978). Native plant species have been known to occur in a diversity of prairie types (Gleason and Cronquist 1964; Robertson et al. 1995; Ladd and Oberle 2005; Corbett and Anderson 2006). For example, multiple species of prairie forbs such as Echinacea pallida, Silphium laciniatum, Lobelia spicata and Euphorbia 
corollata occur in tallgrass and hill prairies (Gleason and Cronquist 1964; Robertson et al. 1995; Corbett and Anderson 2006). There are few prairie forbs (herbaceous flowering plants that are not a graminoids) that can be found in tallgrass and sand prairies (White and Madany 1978). However, Chamaecrista fasciculata (partridge pea), the focus of this study, frequently occurs in both sand and tallgrass prairies (White and Madany 1978).

Sand and tallgrass prairies differ in abiotic characteristics such as soil quality, moisture, and geographic distribution. Differences in these abiotic characteristics can result in differences in how the soil retains both moisture and nutrients. Further, differences soil traits can alter the local microbial community, which may alter the composition of the plant community (Bever et al. 2010). Abiotic differences, specifically soil, can also lead to differentiation in the population traits of $C$. fasciculata. For example, soil source can affect the reproductive fitness of $C$. fasciculata populations across tallgrass sites resulting in greater flower production in sites that have a greater amount of organic matter in the soil (Adala-Roberts and Marquis 2007).

Further, the transfer of pollen between populations of $C$. fasciculata limits gene flow. Pollinator flight and pollen movement result in a density dependent relation, the area that pollen travels is larger when flower density is lower while the area pollen travels is lower when flower density is higher in a site (Fenster 1991). Consequently, populations of C. fasciculata are observed to be subdivided into smaller breeding units of related individuals within the same population (Fenster 1991). While pollen does travel between populations under scenarios where there is low flower density, epistasis reduces the fitness of these hybrid offspring limiting successful gene flow between populations (Fenster and Galloway 2000a, 2000b).

Chamaecrista fasciculata's response to particular environmental conditions may depend on if there is local adaptation to the sand vs. tallgrass prairies. There has been considerable study 
of reproduction and survival of $C$. fasciculata, which have demonstrated local and regional adaptation (Etterson 2004; Fenster and Galloway 2000a, 2000b). In a previous study that assessed the extent of adaptation at different spatial scales along an east to west environmental gradient in eastern North America (Maryland, Illinois, Kansas) used a series of experimental plots, evidence was found for local adaptation of C. fasciculata (Galloway and Fenster 2000). The species also has locally adapted ecotypes across a north to south climactic gradient in Midwestern North America (Minnesota to Oklahoma) (Etterson 2004). In Illinois, small and larger size populations were compared in a greenhouse study concluding smaller populations had a greater genetic load thus some smaller populations may be less able to adapt to environmental changes (Mannouris and Byers 2013). Further, reciprocal transplant studies have also been conducted on a local scale in this plant, comparing the trait values of differing ecotypes in South Dakota (Finney et al. 2016). Specifically, finding that the dry upland ecotype allocated double the amount of aboveground biomass to reproductive structures than the marshland ecotype while the marshland ecotype produced larger but fewer seeds (Finney et al. 2016). However, to my knowledge there are no studies focused on population differentiation of $C$. fasciculata across sand and tallgrass prairies.

Given the variation in habitat characteristics that $C$. fasciculata is subject to and limited gene flow between populations, tallgrass and sand prairie populations may encounter different selective pressures. Further, there is the potential that populations from sand and tallgrass habitat types will respond differently to a competitor that is found in both habitat types. I hypothesize that $C$. fasciculata populations from tallgrass prairies have been selected for growing in taller and denser vegetation, thus they are more successful in tolerating competitors, when competing for light resources, in regard to their ability to grow and reproduce alongside a competitor, 
Schizachyrium scoparium (little bluestem), than populations from sand prairies. Further, I predict that $C$. fasciculata tallgrass prairie populations will grow taller and produce greater biomass and more fruit when planted with a competitor in comparison to plants from sand prairie populations.

\section{Methods}

Study Species

Chamaecrista fasciculata Michz. (Fabaceae) is an annual plant with a self-compatible breeding system but a mixed mating system (selfing and outcrossing) due to the flowers being mostly pollinated by bumblebees (Bombus spp.) who tend to visit a limited number of flowers on a plant before moving to another (Irwin and Barneby 1982; Fenster 1991). Pollination occurs when the plant receives floral sonication from bumblebees that create vibrations in $C$. fasciculata's flowers via fast contractions of their indirect flight muscles which results in pollen being shed through the anthers pores. After pollen is shed, the pollinator visits multiple flowers on the same plant before moving onto another plant (personal observation). Pollen is the only floral reward for pollinators of this species.

Chamaecrista fasciculata is a widespread species found in a diversity of habitat types across the species range in North America, within the prairie peninsula region of Illinois and Indiana it is commonly found in different types of prairies - dry and moist sand prairies and moist tallgrass prairies as well as sandy savannas (Ladd and Oberle 2005; personal observations). However, for this specific study, I am only including the more divergent habitats - dry sand and moist tallgrass prairie types to test if prairie type has an impact on competitive ability. Seedlings emerge over a several week period from mid-April through mid-May, flowering begins mid- July and continues through the first frost, maturing fruits begin to appear in late summer or early 
autumn after which the plants go into senescence (Galloway and Fenster 2000; personal observations). Although seeds can remain dormant for one year, this species is not shown to have a long-term seed bank (Baskin and Baskin 1988).

\section{Prairie Seed Sources}

In order to formally quantify the abiotic and biotic characteristics of sand and tallgrass prairies containing $C$. fasciculata, I characterized the vegetation and sampled the soil at three dry sand and three moist tallgrass prairies with populations of $C$. fasciculata (Table 1). For the vegetation assessment, fifteen plots $(1 \mathrm{~m} \times 0.5 \mathrm{~m})$ were setup in each field site in areas where $C$. fasciculata was present to sample for the number of individual plants present and the percent cover of each species present. A quadrat frame (with markings at $025,0.5$ and $0.75 \mathrm{~m}$ ) was used in all sample plots to assist in determining the percent cover. The percent cover was determined by judging the area covered by each species within each sample plot. All vegetation and soil data were collected in July 2014, when C. fasciculata was flowering. The number of individuals present for each species, the number of species, and their percent cover was used to calculate species diversity with the Shannon-Weiner Index $\left(H^{\prime}=\sum_{i=1}^{R} p_{i} \ln p_{i}\right)$.

To quantify the potential differences in size of the plants within each of the field sites I measured the height of three randomly selected $C$. fasciculata plants within each vegetation plot, and the height of the three tallest plants, that were not $C$. fasciculata, present within each of these plots. The three tallest plants present were then identified to species.

Soil samples for nutrient and physical analysis were taken at each of the sites by haphazardly taking ten to fifteen soil samples via a thirty-centimeter depth soil corer throughout the location of the population of $C$. fasciculata and then mixed for each site. These soil samples were analyzed for soil nutrients ( $\mathrm{N}$ as nitrate, $\mathrm{P}$, and $\mathrm{K}$ ), $\mathrm{pH}$, percent organic matter, and physical 
texture of each site's soil by the University of Wisconsin Soil and Forage Laboratory - Extension Service (https://uwlab.soils.wisc.edu/).

From August 2014 to September 2014, C. fasciculata seeds, by maternal family, were collected from the three sand prairies and the three tallgrass prairies. Seeds were collected from fruits of enough plants to ensure having at least twenty-four families per site for the greenhouse study. Seeds collected were then scarified using a multi-surface fine grit sandpaper and put through a moist cold treatment in order to induce germination. All seeds were collected from area within the sites that are either remnants or in the case of Goose Lake State Park partly restored remnant (Table 1).

\section{Experimental Design}

To test the effect of prairie type and competition on the plants throughout this study, I conducted a greenhouse competition experiment using a nested factorial experimental design. Two types of treatments were used for this study. First, a competition treatment that was a $C$. fasciculata grown alone in a pot vs. a $C$. fasciculata grown with a competitor in the same size pot. For the competitor an individual C. fasciculata plant was grown in the pot with an individual Schizachyrium scoparium Michz. (Poaceae) plant. Second, a prairie type treatment (tallgrass vs. sand), where the above $C$. fasciculata plants grown from seeds that were collected from tallgrass or sand prairie populations. For each prairie type, three randomly chosen populations were used. Seed source populations are nested within prairie type.

Plants were grown in a square pot (9.5 $\mathrm{x} 4$ inches) that was filled with a 1:1 ratio mix of perlite and Metro-Mix soil \#902 (770 Silver Street Agawam, MA 01001). Each pot was then randomly assigned one seed source (a population within one of the prairies where the seed was collected) and a competition treatment until all of the twelve combinations were met. Each 
combination of seed source and competition treatment was replicated 24 times by using different maternal families from each population for the different competition treatments. By using maternal lines each populations potential maternal effect does not confound the competition treatment within a population. Schizachyrium scoparium seeds were purchased from Prairie Moon Nursery (32115 Prairie Lane, Winona, MN, 55987) in order to have a neutral seed source that was not associated with either prairie type. The competitor was started before $C$. fasciculata was introduced to the pot (December 2014) as $C$. fasciculata in field sites competes with plants that are already established. Once the moist cold treatment was complete, individual $C$. fasciculata seeds were transplanted to their respective pots on January 2, 2015. Throughout the study the plants were watered every other day until a $C$. fasciculata plants went into senescence. Further, a weak fertilizer mixer (1 teaspoon / 5 liters of water) using Peters Special Purpose Fertilizer 20-20-20 (6656 Grant Way, Allentown, PA, 18106) was used at the start of the study to not stress the seedlings for nutrients.

\section{Plant Assessment}

To evaluate if the tallgrass prairie type plants were better competitors in relation to growth, two types of measurements were used, height and biomass. For height, each $C$. fasciculata plant was measured on the $30^{\text {th }}, 60^{\text {th }}$, and $90^{\text {th }}$ day after the plant's germination. Height was measured from the base to the tip of the shoot of each plant. The aboveground vegetative and fruit biomass of each plant and their competitor's aboveground vegetative biomass was harvested when each plant began to go into senescence. Fruit biomass of each plant was collected throughout the experiment when individual fruits reached maturity. All collected biomass was then placed in a drying oven at $60{ }^{\circ} \mathrm{C}$ for at least 48 hours and weighed to the nearest fourth decimal place in grams. 
To assess if plants from the tallgrass prairie type were better competitors in relation to reproduction, the number of fruits each $C$. fasciculata plant produced was also recorded. Fruit production required hand pollination given the lack of bumblebees in the greenhouse. Hand pollination was achieved by using bee sticks (dried honeybee thorax glued to a toothpick), all flowering plants were pollinated each day during flowering throughout the experiment.

The timing of developmental changes was assessed by recording the day since germination of the first flower for each $C$. fasciculata plant and its height at that time. The day of senescence when the plant was harvested was also recorded.

\section{Statistical Analyses}

Overall, I used a nested factorial ANOVA approach where prairie type and competition treatment and their interaction were fixed effects. Population was nested within prairie type. Population and the interaction between population nested within prairie type and competition treatment were treated as random effects. The GLM procedure in SAS version 9.4 statistical package was used for these analyses (SAS 2012).

To assess height over the experiment (30,60 and 90 days after germination) a nested factorial repeated measures ANOVA was used to determine the effect of prairie type, competition, populations within prairie type, and the interactions. Profile analysis was used to assess for differences in rate of grow due to the prairie type. To meet the assumptions of a repeated measures, height was natural log transformed.

A nested factorial MANOVA was used to determine if the prairie type, competitor, the nested effect of population, and their interactions impacted the flowering time and senescence as well as height at these times of the $C$. fasciculata. Standardized canonical coefficients were used to determine the relative contribution of the response variables to any significant treatment 
effects. The timing of flowering and senescence and the height on individual plants at these times were natural log transformed to meet assumptions.

A nested factorial ANOVA was used to assess if prairie type, the competition treatment, or their interactions affected the final size of the $C$. fasciculata plants (aboveground vegetative biomass and fruit biomass). MANOVA was not used for the biomass data since some plants did not reproduce. Aboveground biomass was natural log transformed and fruit biomass was square root transformed to meet the assumptions of a nested factorial ANOVA.

\section{Results}

Field sites differed from each other in relation to soil composition and height of plants in the sampled plots. In the tallgrass sites (Weston Cemetery Prairie Nature Preserve, Denby Prairie Nature Preserve, Goose Lake State Park) the soil physical texture varied among the sites but has greater amounts silt and clay than any of the sand prairie sites (Table 1). While in the sand prairie sites (Henry Allen Gleason Nature Preserve, Sand Prairie Scrub Oak Nature Preserve, Sand Ridge State Forest) the soil physical texture was composed of mostly sand ( $94 \%)$ with small amounts of clay and silt (Table 1). The organic matter found in the soil differed between prairie types, where the percent organic matter in tallgrass sites ranged from $3.6 \%$ to $6.7 \%$ while

all sand prairie sites percent organic matter was $\sim 1 \%$ (Table 1). The sites sampled varied greatly in size (hectares) (Appendix A). The height of $C$. fasciculata and the tallest plant species within the sample plots were also taller in the tallgrass prairie sites versus the sand prairie sites (Table 2). There was no pattern in the diversity of species surrounding $C$. fasciculata of the tallgrass vs. sand prairie sites as determined by the Shannon-Weiner diversity index or number of species (Table 2). 
The plants when grown with the competitor were negatively affected as shown in all traits assessed in this study. The height of the plants over time was significantly affected by the competition treatment and the interaction between competition treatment and prairie type (Fig. 1, Tables 3 and 4). Plants also produced less aboveground and fruit biomass in comparison to the plants that were not grown with a competitor (Fig 2). Further, the time it took for plants to begin flowering and go into senescence was also impacted by the presence of the competitor. Plants grown with a competitor took longer to flower and go into senescence than those without a competitor (Fig. 5).

The interaction between prairie type and competition affected height over time (Fig. 1). A profile analysis indicated that height at days 30 to 60 were not significantly different for this interaction but days 60 to 90 were significantly different (Fig. 1, Table 3). Plant height from the $60^{\text {th }}$ to the $90^{\text {th }}$ day after germination for both sand and tallgrass seed sources was shorter when grown with a competitor (Fig. 1). It is important to note that while the interaction between prairie type and the competition treatment is significant, prairie type did not significantly influence plant height, thus it's likely that the competition treatment is driving the interaction. Populations within prairie types and their interaction with competition did not contribute to the variation in height over the experiment (Table 3).

The assessment of biomass found that aboveground vegetative and fruit biomass of the plants growing with a competitor were significantly smaller in comparison to plants grown without a competitor present (Fig. 2, Tables 5 and 6). The prairie types did not significantly affect the production of aboveground vegetative biomass and fruit biomass (Tables 5 and 6). Populations within prairie types and the interaction with competition did not contribute to the variation in biomass production (Tables 5 and 6). 
The number of fruits produced was significantly affected by the competition treatment and the prairie type (Table 7). The competition treatment negatively affected the mean number of fruits produced on each plant (Fig. 3). Furthermore, the sand prairie plants produced more fruits in comparison to the tallgrass prairie plants (Fig. 4). The random effects did not contribute to the variation in fruit production (Table 7).

The number of days for $C$. fasciculata to begin flowering and go into senescence significantly differed due to competition treatment and prairie type (Table 8). Plants grown with the competitor took longer to flower and go into senescence than those not grown with the competitor (Fig. 5). The number of days it took to begin flowering and go into senescence was also greater in plants from the tallgrass prairie sites in comparison to the sand prairie plants (Fig. 8). Further, the height of $C$. fasciculata significantly differed based on the competition treatment and prairie type (Table 8). Plants grown with a competitor were shorter on both the beginning flowering day and on the day they began to senesce (Fig. 6). Tallgrass prairie plants were also taller on their first flowering day and on the day they began to go into senescence in relation to the sand prairie plants (Fig. 7). The random effects did not contribute to the variation in any measured developmental times (Table 8).

\section{Discussion}

Schizachyrium scoparium negatively impacted $C$. fasciculata in a majority of the traits measured. Further, my results did not find any evidence to support my initial hypothesis of a greater competitor response of the tallgrass source populations. However, sand and tallgrass prairie types did vary in relation to the amount of fruits they produced and the time it took for each population on average to begin flowering and go into senescence. 
Sand prairie plants producing more fruit on average than tallgrass prairie plants was counter to what I had predicted to observe for fruit production during this study. This greater fruit production in sand prairie plants could be due to the low nutrient availability in sand prairie habitats (Table 1). Sand prairie plants may be selected to tolerate the low nutrient availability within the soil in comparison to the plants from tallgrass prairies, where there is a greater availability of limiting nutrients (Table 1). Resource availability within a given environment has been considered a selecting force for plants, where low nutrient habitats produce populations that are resilient to low nutrient availability (Eckstein and Otte 2004). Further, in the annual plants species Helianthus anomalus, populations found in low nutrient, arid habitats have shown to be more resource acquisitive in comparison to populations found in habitats that are less arid and have greater nutrient availability (Brouillette et al. 2013). Tallgrass prairie plants also flowered and went into senescence earlier than sand prairie plants (Fig. 8). Differences in habitat characteristics have shown to result in significant genetic differentiation causing variation in the flowering phenology of populations of grassland plant species (Völler et al. 2017).

While prairie types and the interaction between prairie types and competition treatment significantly affects some measured traits, there was no clear pattern in this greenhouse study that separated sand vs. tallgrass prairie plants responses to the competition treatment. This lack of support for finding differences attributed to prairie type could be due to the artificial nature of greenhouse experiments. This study only compares the response of a $C$. fasciculata to a single competitor. The soil mixture used for the experiment may also have affected the results as it was made to be well drained to prevent fungal pathogens. Thus, this well-drained soil mixture may simulate a sandier soil as found in the sand prairies. Further, light availability in the greenhouse does not simulate the light typically available for prairie plants as greenhouses have lower level 
of light than field conditions and this greenhouse is shaded by surrounding buildings at some times of the day.

As stated previously, the habitat types of seed collection sites did differ in relation to soil composition, nutrient availability, and plant height (Fig. 6; Table 1). Observed environmental differences between these prairie types are a combination of abiotic and biotic factors, which potentially impact survivorship, growth, and reproduction of $C$. fasciculata. It is likely that a common garden or reciprocal transplant study may provide more insight to C. fasciculata's potential responses to a given habitat that this greenhouse study could not.

There are many examples where reciprocal transplant or common garden studies have found evidence of differential responses to local vs. nonlocal habitats (Bischoff et al. 2006; Carter and Blair 2012; Burcharova et al. 2016). Both forb and grass species have shown evidence of local adaptation, where local seed sources exhibit greater success and competitive ability than non-local seed sources (Bischoff et al. 2006; Burcharova et al. 2016). Further, local seed sources have also shown to have greater flower and biomass production in relation to non-local seed sources (Burcharova et al. 2016). In addition, the environmental conditions planted seeds are subjected to, specifically on a North to South climactic gradient, can affect introduced plant species survivorship, where plants further away from their source population experience lower survivorship (Carter and Blair 2012).

As $C$. fasciculata sand and tallgrass prairie plants were found to differ in relation to fruit production and development times in a greenhouse setting, this poses a question, could $C$. fasciculata plants vary in relative success if planted directly in their prairie type vs. an alternate prairie type? Future studies should incorporate common garden and reciprocal transplant studies more into this field of research to test if there are differential responses of plant species that are 
found in divergent habitats. Further, site managers should take into account that $C$. fasciculata populations from different habitat types may differ in response to the restoration that they are introduced. Thus, successfully establishing plant species to a restoration may depend upon the habitat type that populations are selected. 


\section{References}

Aavik, T., Bosshard, D., Edwards, P.J., Holderegger, R., and Billeter R. 2013. Fitness in naturally occurring and restored populations of a grassland plant Lychnis flos-cuculi in a Swiss agricultural landscape. Restoration Ecology. 22(1): 98-106. doi:10.1111/rec.12020.

Abdala-Roberts, L., and Marquis, R.J. 2007. Test of local adaptation to biotic interactions and soil abiotic conditions in the ant-tended Chamaecrista fasciculata (Fabaceae). Oecologia. 154(2): 315-326. doi:10.1007/s00442-007-0831-y.

Adhikari, S., and Russell, F.L. 2014. Effects of apical meristem mining on plant fitness, architecture, and flowering phenology in Cirsium altissimum (Asteraceae). American Journal of Botany. 101(12): 2079-2087. doi:10.3732/ajb.1400210.

Anderson, R.C. 1970. Prairies in the prairie state. Transactions of the Illinois State Academy of Science. 63(1): 214-221.

Aspinwall, M.J., Lowry, D.B., Taylor, S.H., Juenger, T.E., Hawkes, C.V., Johnson, M-V.V., Kiniry, J.R., and Fay, P.A. 2013. Genotypic variation in traits linked to climate and aboveground productivity in a widespread $\mathrm{C} 4$ grass: evidence for a functional trait syndrome. New Phytologist. 199(4): 966-980. doi:10.1111/nph.12341.

Baer, S.G., Gibson, D.J., Gustafson, D.J., Benscoter, A.M., Reed, L.K., Campbell, R.E, and Wodika, B.R. 2013. No effect of seed source on multiple aspects of ecosystem functioning during ecological restoration: Cultivars compared to local ecotypes of dominant grasses. Evolutionary Applications. 7(2): 323-335. doi:10.1111/eva.12124 doi:10.1111/eva.12124.

Baskin C.C., and Baskin, J.M. 1988. Germination ecophysiology of herbaceous plant species in a temperate region. American Journal of Botany. 75(2): 286-305. doi:10.2307/2443896. 
Bever, J.D., Dickie, I.A., Facelli, E., Facelli, J.M., Klironomos, J., Moora, M., Rillig, M.C., Stock, W.D., Tibbett M., and Zobel, M. 2010. Rooting theories of plant community ecology in microbial interactions. Trends in Ecology and Evolution. 25(8): 468-478. doi:10.1016/j.tree.2010.05.004.

Bischoff, A., Crémieux, L., Smilauerova, M., Lawson, C.S., Mortimer, S.R., Dolezal, J., and Müller-Schärer, H. 2006. Detecting local adaptation in widespread grassland species? The importance of scale and local plant community. Journal of Ecology. 94(6): 1130-1142. doi:10.1111/j.1365-2745.2006.01174.x.

Bowles, M.L., McBride, J.L., and Bell, T.J. 2015. Long-term processes affecting restoration and viability of the federal threatened mead's milkweed (Asclepias meadii). Ecosphere. 6(1): 122. doi:10.1890/es14-00240.1.

Brouillette, L. C., Mason, C.M., Shirk, R.Y., and Donovan, L.A. 2013. Adaptive differentiation of traits related to resource use in a desert annual along a resource gradient. New Phytologist. 201(5):1316-1327.

Bucharova, A., Michalski, S., Hermann, J., Heveling, K., Durka, W., Hölzel, N., and Bossdorf, O. 2016. Genetic differentiation and regional adaptation among seed origins used for grassland restoration: Lessons from a multispecies transplant experiment. Journal of Applied Ecology. 54(1):127-136. doi:10.1111/1365-2664.12645.

Bucharova, A., Durka, W., Hölzel, N., Kollmann, J., Michalski, S., and Bossdorf, O. 2017. Are local plants the best for ecosystem restoration? It depends on how you analyze the data. Ecology and Evolution. 7(24): 10683-10689. doi:10.1002/ece3.3585. 
Callaway, R.M., Ridenour, W.M., Laboski, T., Weir, T., and Vivanco, J.M. 2005. Natural selection for resistance to the allelopathic effects of invasive plants. Journal of Ecology. 93(3): 576-583. doi:10.1111/j.1365-2745.2005.00994.x

Carter, D.L., and Blair, J.M. 2012. Seed source affects establishment and survival for three grassland species sown into reciprocal common gardens. Ecosphere. 3(11): 1-10. doi:10.1890/es12-00223.1

Carter, D.L., and Blair, J.M. 2013. Seed source has variable effects on species, communities, and ecosystem properties in grassland restorations. Ecosphere. 4(8): 1-16. doi:10.1890/es1300090.1.

Cheplick, G.P. 2015. Approaches to Plant Evolutionary Ecology. Oxford University Press, Oxford.

Clausen, J., Keck, D.D., and Heisey, W.M. 1948. Experimental studies on the nature of species. III. Environmental responses of climatic races of Achillea. Carnegie Institute of Washington. 581.

Corbett, E.A., and Anderson, R.C. 2001. Patterns of prairie plant species in Illinois' landscape. Proceedings of the Seventeenth North American Prairie Conference. North Iowa Area Community College, Mason City, IA.

Corbett, E.A., and Anderson, R.C. 2006. Landscape analysis of Illinois and Wisconsin remnant prairies. The Journal of the Torrey Botanical Society 133: 267-279.

Diamond, J.M. 1975. The island dilemma: Lessons of modern biogeographic studies for the design of natural reserves. Biological Conservation, 7(1):129-146. doi:10.1016/00063207(75)90052-x. 
Eckstein, L.R., and Otte, A. 2004. Evidence for consistent trait-habitat relations in two closely related violets of contiguous habitat types from a fertilization experiment. Flora Morphology, Distribution, Functional Ecology of Plants, 199(2):234-246.

Endler, J.A. 1986. Natural selection in the wild. Monographs in Population Biology. no. 21. Princeton University Press, Princeton.

Espeland, E.K., Emery, N.C., Mercer, K.L., Woolbright, S.A., Kettenring, K.M., Gepts, P., and Etterson, J.R. 2016. Evolution of plant materials for ecological restoration: insights from the applied and basic literature. Journal of Applied Ecology. 54(1): 102-115.

Etterson, J.R. 2004. Evolutionary potential of Chamaecrista fasciculata in relation to climate change. I. clinal patterns of selection along an environmental gradient in the great plains. Evolution. 58(7): 1446-1456.

Evers, R.A. 1955. Hill prairies of Illinois. Bull. 111. Natural History Survey. 26(1): 367-466.

Fenster C.B. 1991. Gene flow in Chamaecrista fasciculata (Leguminosae). I. Gene dispersal. Evolution. 45(2): 308-409. doi:10.2307/2409673.

Fenster, C.B., and Galloway, L.F. 2000a. Inbreeding and outbreeding depression in natural populations of Chamaecrista fasciculata (Fabaceae). Conservation Biology. 14(5): 14061412.

Fenster, C.B., and Galloway, L.F. 2000b. Population differentiation in an annual legume: genetic architecture. Evolution. 54(4): 1157-1172.

Fenster, C.B., Vekemans, X., and Hardy, O.J. 2003. Quantifying gene flow from spatial genetic structure data in a metapopulation of Chamaecrista fasciculata (Leguminosae). Evolution. 57(5): 995-1007. 
Finney, T.E., Gedan, K.B., and Fenster, C.B. 2016. Allocation patterns contribute to the distributional limits of a flood tolerant ecotype of Chamaecrista fasciculata. Aquatic Botany. 134(1):31-38.

Gallagher, M.K., and Wagenius, S. 2016. Seed source impacts germination and early establishment of dominant grasses in prairie restorations. Journal of Applied Ecology. 53(1): 251-263. doi:10.1111/1365-2664.12564.

Galloway, L.F., and Fenster, C.B. 2000. Population differentiation in an annual legume: local adaptation. Evolution. 54(4):1173-81.

Galloway, L.F., and Fenster, C.B. 2001. Nuclear and cytoplasmic contributions to intraspecific divergence in an annual legume. Evolution. 55(3): 488-497.

Gleason, H.A., and Cronquist, A. 1964. The natural geography of plants. Columbia University Press, New York.

Gray, M.M., Amand, P.S., Bello, N.M., Galliart, M.B., Knapp, M., Garrett, K.A., Morgan, T.J., Baer, S.G., Maricle, B.R., Akhunov, E.D., and Johnson, L.C. 2014. Ecotypes of an ecologically dominant prairie grass (Andropogon gerardii) exhibit genetic divergence across the U.S. Midwest grasslands' environmental gradient. Molecular Ecology. 23(24): 60116028.

Goldberg, D.E., and Landa, K. 1991. Competitive effect and response: hierarchies and correlated traits in the early stages of competition. The Journal of Ecology. 79(4): 1013-1030. doi:10.2307/2261095

Harr, R.N., Wright Morton, L., Rusk, S.R., Engle, D.M., Miller, J.R., and Debinski, D. 2014. Landowners' perceptions of risk in grassland management: woody plant encroachment and prescribed fire. Ecology and Society 19(2): 41-53. 
Herget, M., Hufford, K., Mummey, D., Mealor, B., and Shreading, L. 2015. Effects of competition with Bromus tectorum on early establishment of Poa secunda accessions: can seed source impact restoration success?. Restoration Ecology 23(3): 277-283.

Hobbs, R.J., and Cramer, V.A. 2008. Restoration ecology: Interventionist approaches for restoring and maintaining ecosystem function in the face of rapid environmental change. Annual Review of Environment and Resources. 33(1): 39-61. doi:10.1146/annurev.energy.33.020107.113631.

Hobbs, R.J., Hallett, L.M., Ehrlich, P.R., and Mooney, H.A. 2011. Intervention ecology: Applying ecological science in the twenty-first century. BioScience. 61(6): 442-450. doi:10.1525/bio.2011.61.6.6.

Irwin, H.S., and Barneby, R.C. 1982. The American Cassiinae: A synoptical revision of Leguminosae tribe Cassieae subtribe Cassiinae in the new world. Kew Bulletin. 39(1): 636664. doi:10.2307/4108613

Ison, J.L., Wagenius, S., Reitz, D., and Ashley, M.V. 2014. Mating between Echinacea angustifolia (Asteraceae) individuals increases with their flowering synchrony and spatial proximity. American Journal of Botany. 101(1): 180-189.

Jackson, R.D., Paine, L.K., and Woodis, J.E. 2010. Persistence of native C4 grasses under highintensity, short-duration summer bison grazing in the eastern tallgrass prairie. Restoration Ecology. 18(1): 65-73. doi:10.1111/j.1526-100x.2008.00439.x. 
Johnson, L.C., Olsen, J.T., Tetreault, H., Delacruz, A., Bryant, J., Morgan, T.J., Knapp, M., Bello, N.M., Baer, S.G., Maricle B.R. 2015. Intraspecific variation of a dominant grass and local adaptation in reciprocal garden communities along a US Great Plains' precipitation gradient: implications for grassland restoration with climate change. Evolutionary Applications. 8(7): 705-723.

Johnson, N.C., Wilson, G.W.T., Bowker, M.A., Wilson, J.A., and Miller, R.M. 2010. Resource limitation is a driver of local adaptation in mycorrhizal symbioses. Proceedings of the National Academy of Sciences. 107(5):2093-2098.

Kim, E., and Donohue, K. 2013. Local adaptation and plasticity of Erysimum capitatumto altitude: Its implications for responses to climate change. Journal of Ecology. 101(3): 796805. doi:10.1111/1365-2745.12077.

Kindell, C.E., Winn, A.A., and Miller, T.E. 1996. The effects of surrounding vegetation and transplant age on the detection of local adaptation in the perennial grass Aristida stricta. Journal of Ecology. 84(5): 745-754. doi:10.2307/2261336

Koch, K.G., Bradshaw, J.D., Heng-Moss, T.M., and Sarath, G. 2014. Categories of resistance to greenbug and yellow sugarcane aphid (Hemiptera: Aphididae) in three tetraploid switchgrass populations. BioEnergy Research. 7(3): 909-918.

Ladd, D.M., and Oberle, F. 2005. Tallgrass prairie wildflowers: a field guide to common wildflowers and plants of the prairie Midwest. Falcon Guilford.

Lauterbach, D., Ristow, M., and Gemeinholzer, B. 2011. Population genetics and fitness in fragmented populations of the dioecious and endangered Silene otites (Caryophyllaceae). Plant Systematics and Evolution. 298(1): 155-164. doi:10.1007/s00606011-0533-0. 
Leimu, R., and Fischer, M. 2008. A meta-analysis of local adaptation in plants. PLoS ONE. 3(12): e4010.

Lindborg, R., and Eriksson, O. 2004. Historical landscape connectivity affects present plant species diversity. Ecology 85(7): 1840-1845.

Lowry, D., and Willis, J. 2010. A widespread chromosomal inversion polymorphism contributes to a major life-history transition, local adaptation, and reproductive isolation. PLoS Biology. 10(1): e1000500.

Lowry, D.B., Behrman, K.D., Grabowski, P., Morris, G.P., Kiniry, J.R., and Juenger, T.E. 2014. Adaptations between Ecotypes and along Environmental Gradients in Panicum virgatum. The American Naturalist. 183 (5): 682-692.

Mannouris, C., and Byers, D.L. 2013. The impact of habitat fragmentation on fitness-related traits in a native prairie plant, Chamaecrista fasciculata (Fabaceae). Biological Journal of the Linnean Society. 108(1): 55-67.

Rios, R.S., Marquis, R.J., and Flunker J.C. 2008. Population variation in plant traits associated with ant attraction and herbivory in Chamaecrista fasciculata (Fabaceae). Oecologia. 156(3): 577-588.

Robertson, K.R., Schwartz, M.W., Olson, J.W., Dunphy, B.K., and Clarke, H.D. 1995. Fifty years of change in Illinois hill prairies. Erigenia. 14(1): 41- 52.

Rowe, H.I., Fargione, J., and Holland, J.D. 2013. Prairie Restorations can protect remnant tallgrass prairie plant communities. The American Midland Naturalist. 170(1): 26-38. doi:10.1674/0003-0031-170.1.26 
Rutter, M.T., and Rausher, M.D. 2004. Natural selection on extrafloral nectar production in Chamaecrista fasciculata: the costs and benefits of a mutualism trait. Evolution. 58(12): 2657-2668.

SAS. 2012. SAS version 9.4. SAS Institute, Cary, NC

Smith, D.D. 2010. The Tallgrass Prairie Center guide to prairie restoration in the Upper Midwest. University of Iowa Press, Iowa City.

Völler, E., Bossdorf, O., Prati, D., and H. Auge, H. 2017. Evolutionary responses to land use in eight common grassland plants. Journal of Ecology 105(5): 1290-1297.

White, J., and Madany, M.H. 1978. Classification of natural communities in Illinois. Illinois Natural Areas Inventory Technical Report. Volume 1: Survey Methods and Results. 1(1): $310-405$. 


\section{Tables}

Table 1. Prairie Soil Characteristics. Soil characteristics of the prairie sites used in the greenhouse study. Chamaecrista fasciculata seeds were collected from each of the sites.

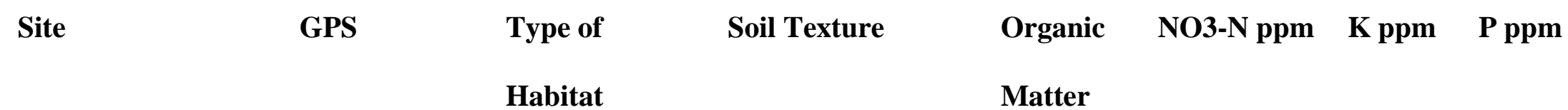

\begin{tabular}{|c|c|c|c|c|c|c|c|}
\hline Weston Nature & N40.7467, & moist tallgrass & $28 \%$ sand, $57 \%$ silt, & $6.70 \%$ & 2.25 & 137 & 4 \\
\hline Preserve, IL & W-88.6145 & & $15 \%$ clay & & & & \\
\hline Denby Nature & N39.2414, & moist tallgrass & $14 \%$ sand, $64 \%$ silt, & $3.60 \%$ & 1.43 & 78 & 10 \\
\hline Preserve, IL & W-89.9264 & & $22 \%$ clay & & & & \\
\hline Goose Lake State & N41.3810, & moist tallgrass & $46 \%$ sand, $35 \%$ silt, & $3.90 \%$ & 1.79 & 34 & 3 \\
\hline Park, IL & W-89.691 & & $19 \%$ clay & & & & \\
\hline Sand Prairie Scrub & N40.1667, & dry sand prairie & $94 \%$ sand, $1 \%$ silt, & $0.90 \%$ & 1.47 & 24 & 62 \\
\hline Oak Nature & W-90.0793 & & $5 \%$ clay & & & & \\
\hline Preserve, IL & & & & & & & \\
\hline
\end{tabular}




\begin{tabular}{|c|c|c|c|c|c|c|c|}
\hline Site & GPS & $\begin{array}{l}\text { Type of } \\
\text { Habitat }\end{array}$ & Soil Texture & $\begin{array}{l}\text { Organic } \\
\text { Matter }\end{array}$ & NO3-N ppm & K ppm & P ppm \\
\hline Henry Allen & N40.3796, & dry sand prairie & $94 \%$ sand, $1 \%$ silt, & $1 \%$ & 0.78 & 17 & 17 \\
\hline Gleason Nature & W-89.9292 & & $5 \%$ clay & & & & \\
\hline Preserve, IL & & & & & & & \\
\hline Sand Ridge State & N41.6133, & dry sand prairie & $94 \%$ sand, $1 \%$ silt, & $0.70 \%$ & 0.64 & 20 & 33 \\
\hline Forest, IL & W-87.5541 & & $5 \%$ clay & & & & \\
\hline
\end{tabular}


Table 2. Natural Prairie Vegetation Data. Species composition and mean $( \pm \mathrm{SE})$ height of $C$. fasciculata and the tallest species within each site sampled plots. The tallest plants in the tallgrass prairie were Andropogon gerardii, Silphium laciniatum, and Schizachyrium scoparium. The tallest plants in the sand prairie were Schizachyrium scoparium, Panicum virgatum, and Elymus Canadensis.

Site Shannon-Weiner Number of Species per $\quad$ C.fasciculata Tallest Species

Index Sample Plot Height $(\mathrm{cm}) \quad$ Height $(\mathrm{cm})$

Weston Nature Preserve, IL 2.0892

11.13

$69.91 \pm 11.62$

$101.37 \pm 3.41$

Denby Nature Preserve, IL 1.60337

$101.27 \pm 11.23$

$146.68 \pm 10.25$

Goose Lake State Park, IL 1.25849

Sand Prairie Scrub Oak

1.40018

Nature Preserve, IL

Henry Allen Gleason Nature 1.37961

Preserve, IL

Sand Ridge State Forest, IL 1.66678
$76.16 \pm 11.62$

$101.92 \pm 2.96$

$31.91 \pm 5.36$

$85.51 \pm 4.63$

$81.22 \pm 3.87$

$43.97 \pm 16.72$

5.93


Table 3. Repeated Measures Height Analysis. Results for repeated measures analysis of height in response to competition treatment, prairie type, the nested random effect of populations, their interactions, and all interacting with time (measurements 30, 60 and 90 days after germination). Height was natural log transformed to meet the assumptions of the analysis.

\begin{tabular}{llllll} 
Source & DF & Type III SS & Mean & F Ratio & Probability \\
& & & Square & Value \\
\hline Time & 2 & 155.626 & 77.813 & 2146.24 & $<0.0001$ \\
Time*Competition Treatment & 2 & 3.766 & 1.883 & 51.94 & $<0.0001$ \\
Time*Prairie Type & 2 & 0.178 & 0.089 & 2.46 & 0.0867 \\
Time*Competition & 2 & 0.304 & 0.152 & 4.20 & 0.0155 \\
Treatment*Prairie Type & & & & & \\
Time*Population(Prairie & 8 & 0.152 & 0.019 & 0.52 & \\
Type) & & & & & \\
\hline
\end{tabular}


Table 4. Profile Analysis for Height. Results from follow-up profile analysis associated with the repeated measures analysis of height. Only significant effects from the repeated measures analysis are included as sources of variation. Time $1=$ the difference between height at 30 vs. 60 days, Time $2=$ the difference between height at 60 vs. 90 days.

Time 1

DF $\quad$ F ratio Probability DF

Value

Source of Variation

DF

\section{Time 2}

\section{F ratio Probability}

Value

Competition

Prairie Type

$1,255 \quad 21.24$

$<0.0001$

1,255

51.75

$<0.0001$

Competition*Prairie

$5,255 \quad 1.69$

0.1366

5,255

0.16

0.9772

$5,255 \quad 1.21$

0.3056

$5,255 \quad 2.54$

0.0289 
Table 5. Aboveground Biomass Nested ANOVA. Results from nested ANOVA of aboveground vegetative biomass. The aboveground biomass was $\ln$ transformed to meet the ANOVA assumptions.

Source

$$
\text { DF Type III SS Mean }
$$

F Ratio Probability

Square

Value

Competition Treatment

$1 \quad 86.361$

86.361

$87.48<0.0001$

Prairie Type

$1 \quad 0.405$

0.405

0.41

0.5222

Competition Treatment*Prairie

$1 \quad 1.262$

1.262

1.28

0.2593

Type

Population(Prairie Type)

$\begin{array}{lr}4 & 8.272\end{array}$

2.068

2.09

0.0820

Competition

$4 \quad 0.973$

0.243

0.25

0.9117

Treatment*Population(Prairie

Type)

Residual

$254 \quad 250.762$

0.987 
Table 6. Fruit Biomass Nested ANOVA. Results from nested ANOVA of fruit biomass. The aboveground biomass was square root transformed to meet the ANOVA assumptions.

\begin{tabular}{|c|c|c|c|c|c|}
\hline \multirow[t]{2}{*}{ Source } & \multirow[t]{2}{*}{ DF } & \multirow{2}{*}{$\begin{array}{l}\text { Type III } \\
\text { SS }\end{array}$} & \multirow{2}{*}{$\begin{array}{l}\text { Mean } \\
\text { Square }\end{array}$} & \multirow{2}{*}{$\begin{array}{l}\text { F } \\
\text { Ratio }\end{array}$} & \multirow{2}{*}{$\begin{array}{l}\text { Probability } \\
\text { Value }\end{array}$} \\
\hline & & & & & \\
\hline Competition Treatment & 1 & 6.418 & 6.418 & 60.30 & $<0.0001$ \\
\hline Prairie Type & 1 & 0.007 & 0.007 & 0.07 & 0.7950 \\
\hline Competition Treatment*Prairie Type & 1 & 0.225 & 0.225 & 2.12 & 0.1469 \\
\hline Population(Prairie Type) & 4 & 0.500 & 0.124 & 1.17 & 0.3231 \\
\hline Competition & 4 & 0.218 & 0.054 & 0.51 & 0.7263 \\
\hline \multicolumn{6}{|l|}{ Treatment*Population(Prairie Type) } \\
\hline Residual & 233 & 24.802 & 0.106 & & \\
\hline
\end{tabular}


Table 7. Fruit Production Nested Factorial ANOVA. Results from analysis of fruit production. Fruit number was natural logged transformed to meet the ANOVA assumptions.

\begin{tabular}{|c|c|c|c|c|c|}
\hline Source & DF & Type III SS & $\begin{array}{l}\text { Mean } \\
\text { Square }\end{array}$ & F Ratio & $\begin{array}{l}\text { Probability } \\
\text { Value }\end{array}$ \\
\hline Competition Treatment & 1 & 28.027 & 28.027 & 48.66 & $<0.0001$ \\
\hline Prairie Type & 1 & 5.862 & 5.862 & 10.18 & 0.0016 \\
\hline Competition Treatment*Prairie Type & 1 & 0.229 & 0.229 & 0.40 & 0.5286 \\
\hline Population(Prairie Type) & 4 & 3.007 & 0.751 & 1.31 & 0.2683 \\
\hline Competition & 4 & 0.154 & 0.038 & 0.07 & 0.9917 \\
\hline \multicolumn{6}{|l|}{ Treatment*Population(Prairie Type) } \\
\hline Residual & 256 & 147.439 & 0.575 & & \\
\hline
\end{tabular}


Table 8. Developmental Nested Factorial MANOVA. Results from analysis of rate of developmental changes (days to flowering and senescence) and the size of the plants (height) at that time.

$1^{\text {st }}$ Standardized Canonical Coefficients $2^{\text {nd }}$ Standardized Canonical Coefficients

\begin{tabular}{|c|c|c|c|c|c|c|c|c|c|c|c|}
\hline Source of Variation & DF & $\begin{array}{l}\text { Pillai's } \\
\text { Trace }\end{array}$ & $\begin{array}{l}\text { F } \\
\text { ratio }\end{array}$ & $\begin{array}{l}\text { Prob- } \\
\text { ability } \\
\text { Value }\end{array}$ & $\begin{array}{l}\text { Flw. } \\
\text { Day }\end{array}$ & $\begin{array}{l}\text { Sen. } \\
\text { Day }\end{array}$ & $\begin{array}{l}\text { Ht. at } \\
\text { Flw }\end{array}$ & $\begin{array}{l}\text { Ht. at } \\
\text { Sen. }\end{array}$ & $\begin{array}{l}\text { Flw. } \\
\text { Day }\end{array}$ & $\begin{array}{l}\text { Sen } \\
\text { Day }\end{array}$ & $\begin{array}{l}\text { Ht. at } \\
\text { Sen. }\end{array}$ \\
\hline
\end{tabular}

Competition Treatment 4

4

0.2241

17.25

$<0.000$

0.3833

0.0233

0.3352

0.6594

0.6607

0.0251

0.0330

Prairie Type

20
968

$$
0.2325 \quad 2.99
$$

$<0.000$

1

0.7063

0.4258

0.0167

0.7408

0.5336

$-$

0.9240

$0.2475 \quad 0.6614$

Competition
Prairie Typ

$\begin{array}{lll}20, & 0.0699 & 0.86 \\ 968 & & \end{array}$
0.6381
- 0.4349
1.1665

0.3133

0.1868

0.7974

$0.3249 \quad 1.0225 \quad 1.4606$ 


\begin{tabular}{|c|c|c|c|c|c|c|c|c|c|c|c|c|}
\hline \multirow[b]{2}{*}{ Source of Variation } & \multirow[b]{2}{*}{ DF } & \multirow[b]{2}{*}{$\begin{array}{l}\text { Pillai's } \\
\text { Trace }\end{array}$} & \multirow[b]{2}{*}{$\begin{array}{l}\text { F } \\
\text { ratio }\end{array}$} & \multirow[b]{2}{*}{$\begin{array}{l}\text { Prob- } \\
\text { ability } \\
\text { Value } \\
\end{array}$} & \multicolumn{4}{|c|}{$\begin{array}{l}1^{\text {st }} \text { Standardized Canonical } \\
\text { Coefficients }\end{array}$} & \multicolumn{4}{|c|}{$\begin{array}{l}2^{\text {nd }} \text { Standardized Canonical } \\
\text { Coefficients }\end{array}$} \\
\hline & & & & & $\begin{array}{l}\text { Flw. } \\
\text { Day }\end{array}$ & $\begin{array}{l}\text { Sen. } \\
\text { Day }\end{array}$ & $\begin{array}{l}\text { Ht. at } \\
\text { Flw }\end{array}$ & $\begin{array}{l}\text { Ht. at } \\
\text { Sen. }\end{array}$ & $\begin{array}{l}\text { Flw. } \\
\text { Day }\end{array}$ & $\begin{array}{l}\text { Sen. } \\
\text { Day }\end{array}$ & $\begin{array}{l}\text { Ht.at } \\
\text { Flw }\end{array}$ & $\begin{array}{l}\text { Ht. at } \\
\text { Sen. }\end{array}$ \\
\hline $\begin{array}{l}\text { Population (Prairie } \\
\text { Type) }\end{array}$ & $\begin{array}{l}5 \\
242\end{array}$ & 0.2766 & 0.73 & 0.5977 & 0.5336 & 0.9239 & 0.2475 & 0.6614 & 0.8740 & 0.9911 & 0.0583 & 0.3102 \\
\hline $\begin{array}{l}\text { Competition } \\
\text { Treatment*Population } \\
\text { (Prairie Type) }\end{array}$ & $\begin{array}{l}5, \\
242\end{array}$ & 0.3164 & 0.62 & 0.6122 & 0.1408 & 0.7768 & 0.3637 & 0.3915 & 0.4479 & $\overline{-}-1072$ & $\overline{0} .2735$ & $\begin{array}{l}- \\
0.1782\end{array}$ \\
\hline Residual & $\begin{array}{l}4, \\
239\end{array}$ & & & & & & & & & & & \\
\hline
\end{tabular}




\section{Figures}

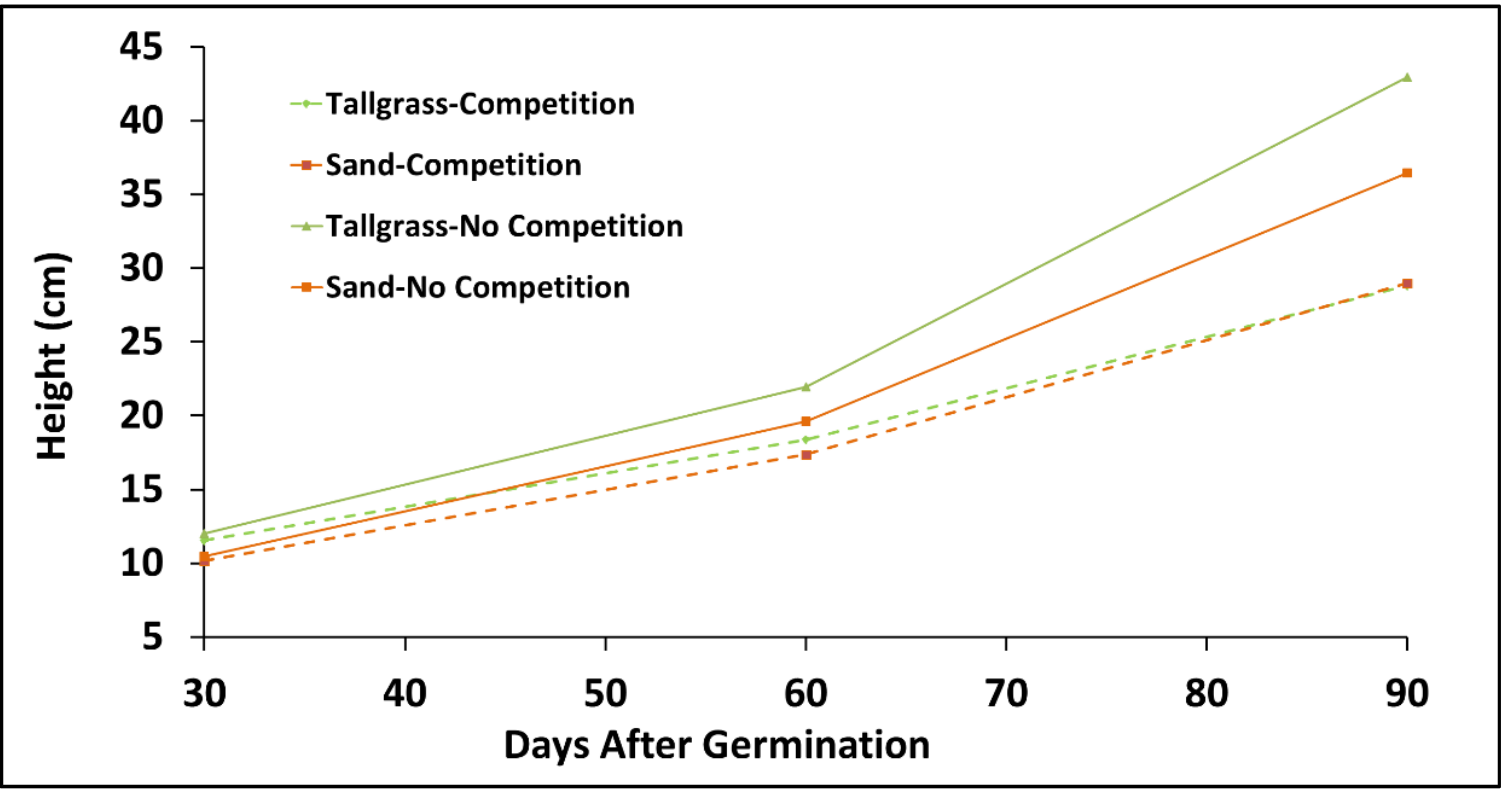

Figure 1. Mean Height. The mean height of each prairie type by competition treatment on the

30th, 60th, and 90th day after germination. The analysis is present on tables 3-A and 3-B. 


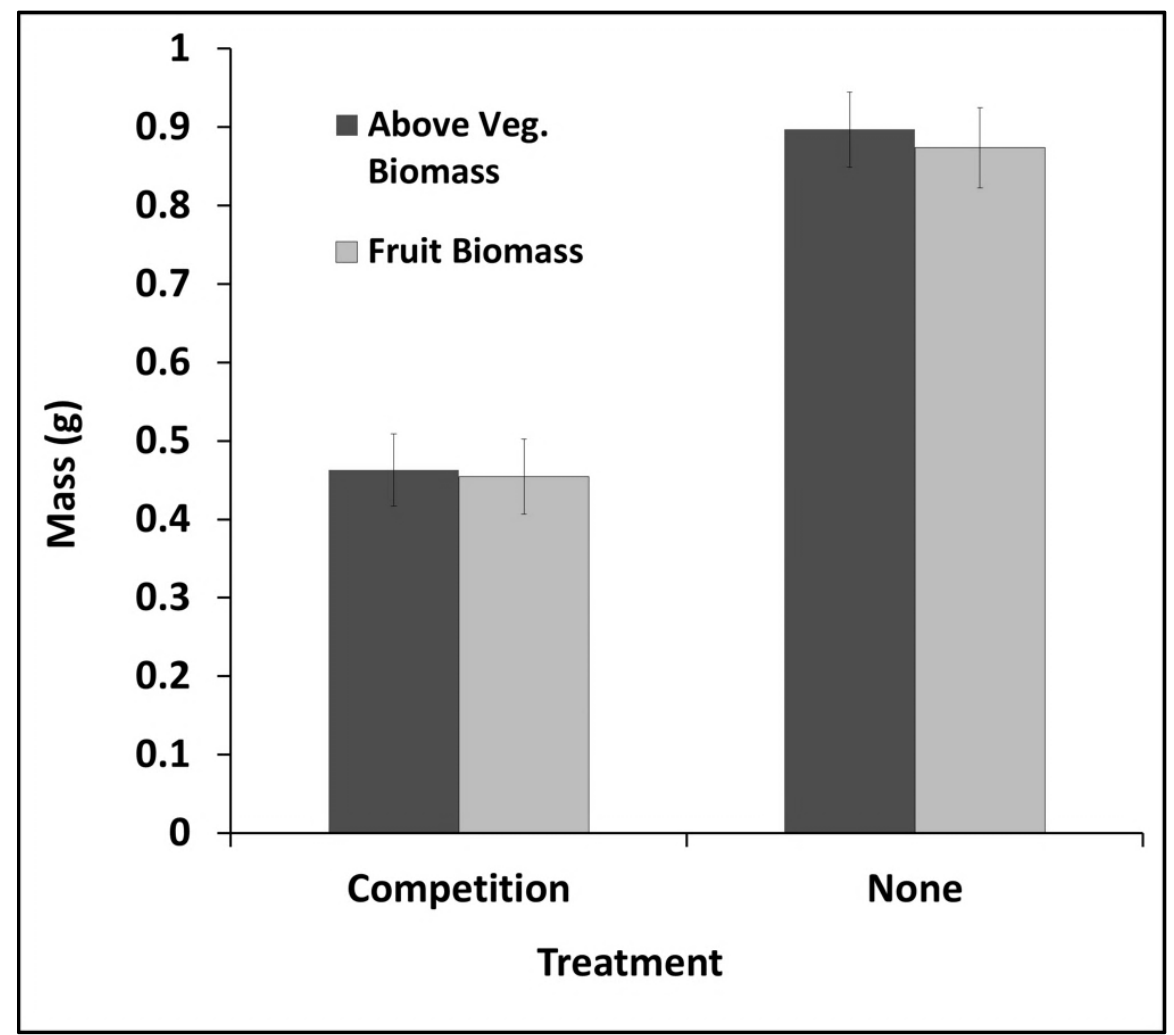

Figure 2. Biomass Production by Competition Treatment. The mean ( $\pm 1 \mathrm{SE})$ aboveground biomass and fruit biomass by competition treatment. The analysis is presented in tables 4 and 5 . 


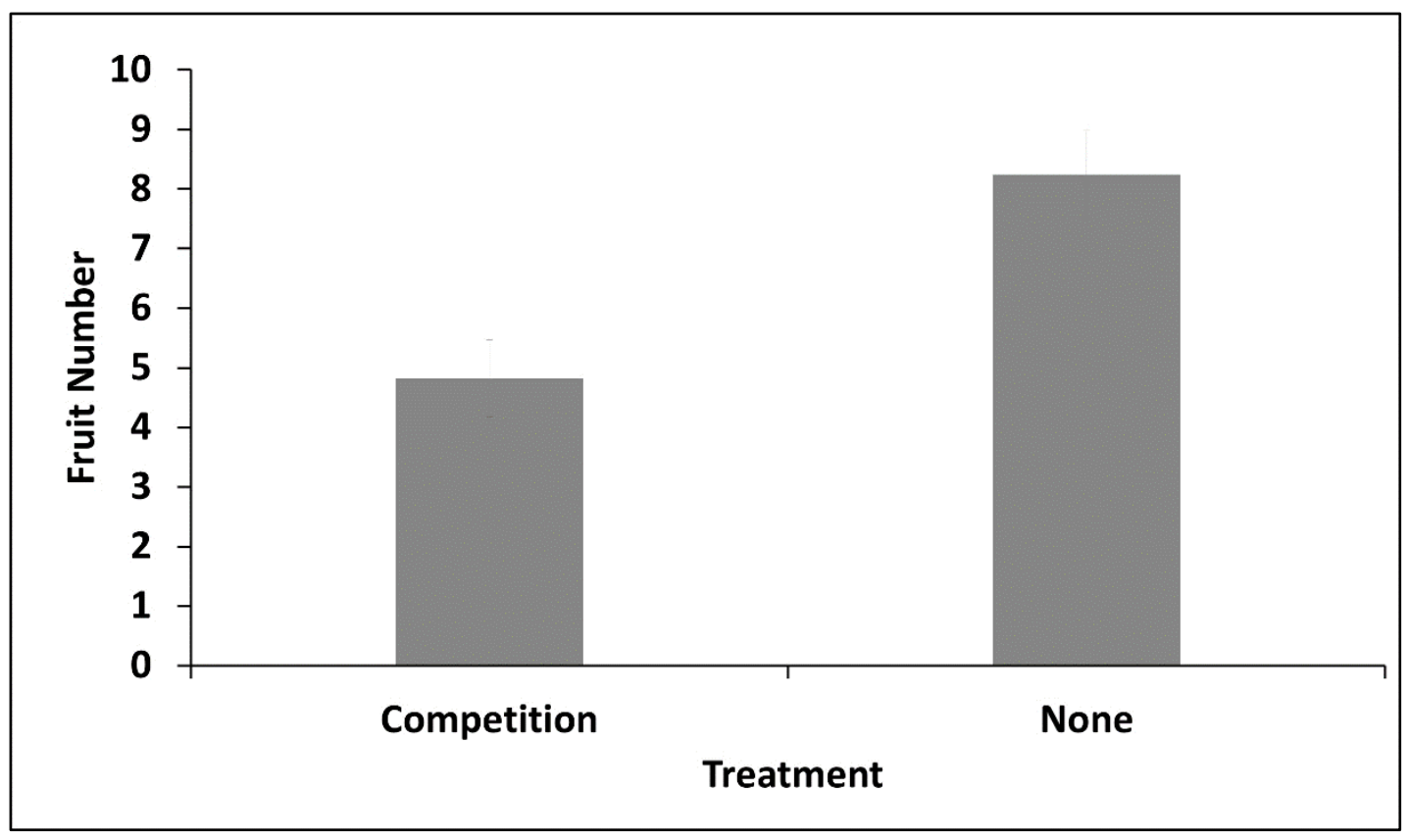

Figure 3. Fruit Production by Competition Treatment. The mean ( $\pm 1 \mathrm{SE})$ fruit production by competition treatment. The analysis is presented in table 6 . 


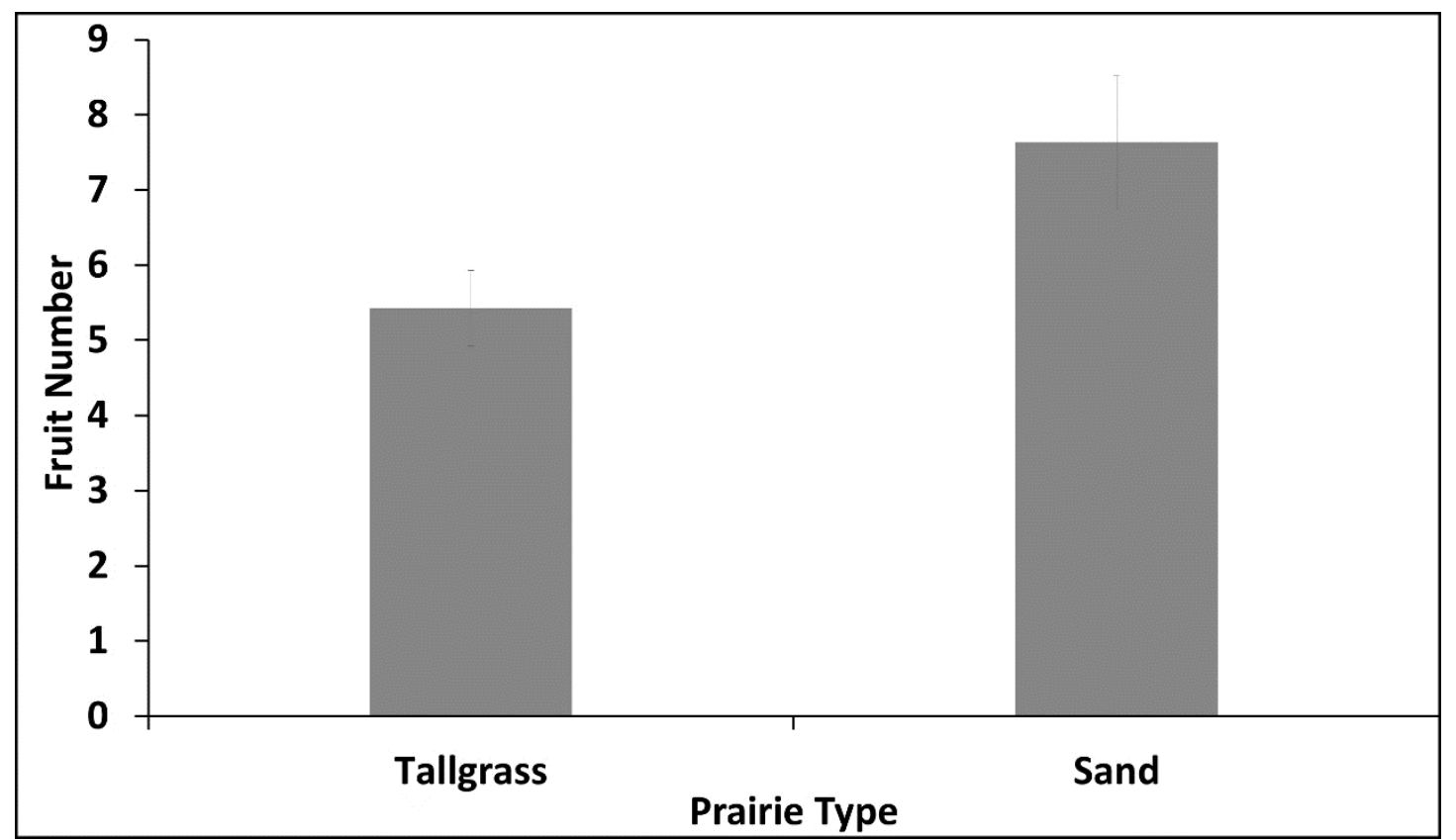

Figure 4. Fruit Production by Prairie Type. The mean ( \pm 1 SE) fruit production by prairie type. The analysis is presented in table 6 . 


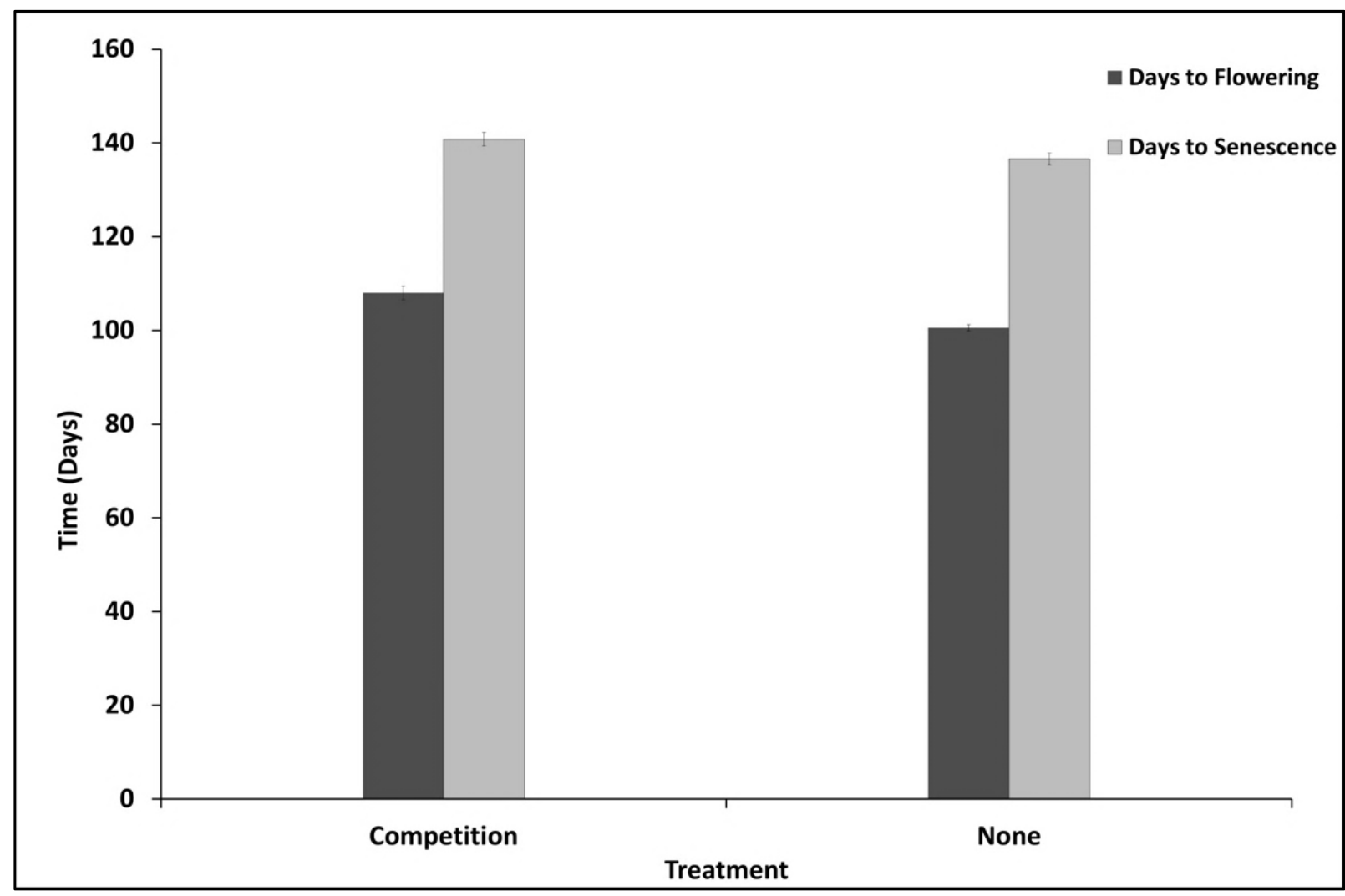

Figure 5. Days to Flowering and Senescence by Treatment. The mean $( \pm 1 \mathrm{SE})$ number of days to flowering and senescence by competition treatment. The analysis is present on table 7 . 


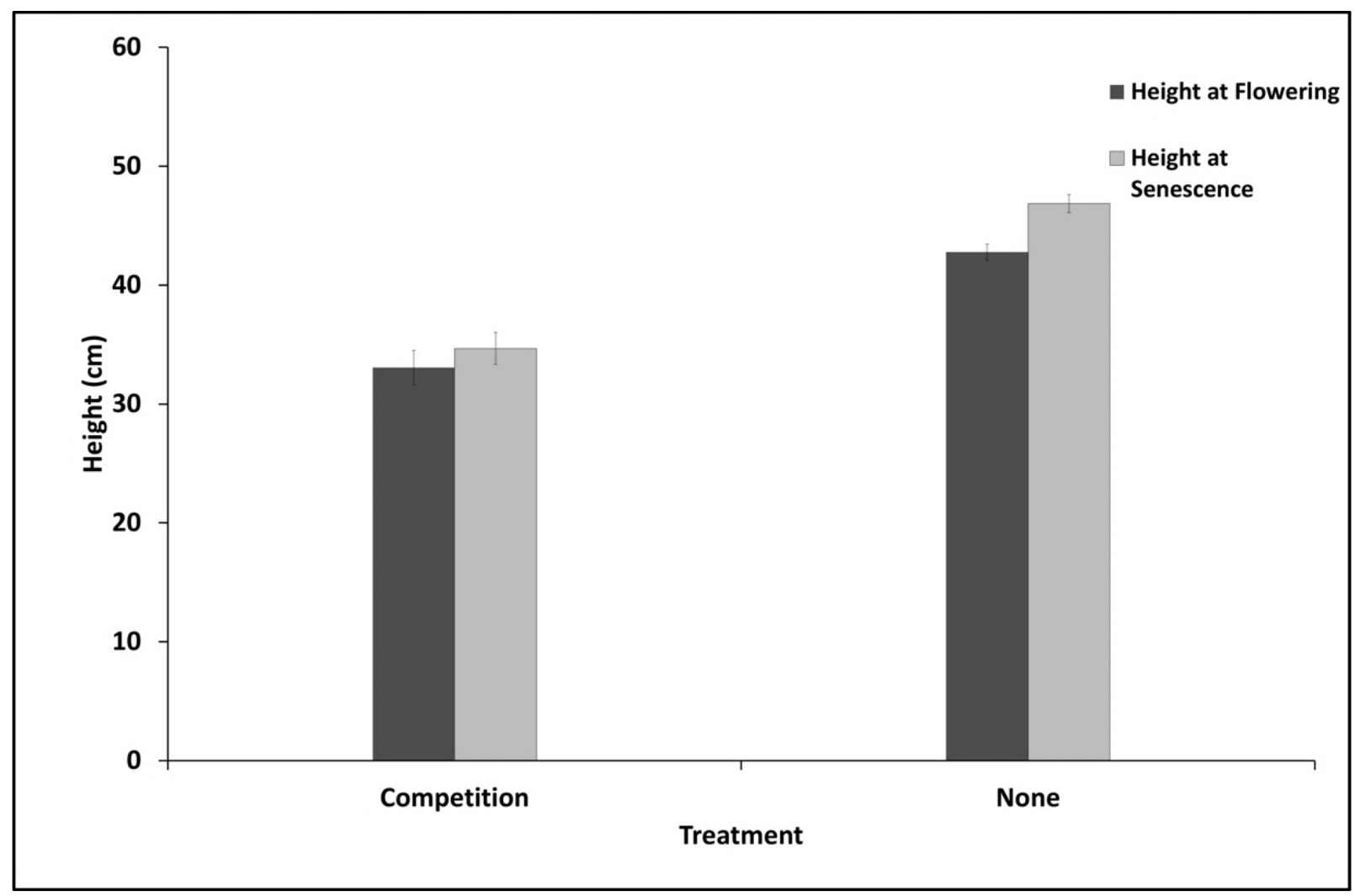

Figure 6. Height at Flowering Day and Senescence by Treatment. The mean ( $\pm 1 \mathrm{SE})$ height of C. fasciculata at flowering and senescence by treatment. The analysis is present on table 7. 


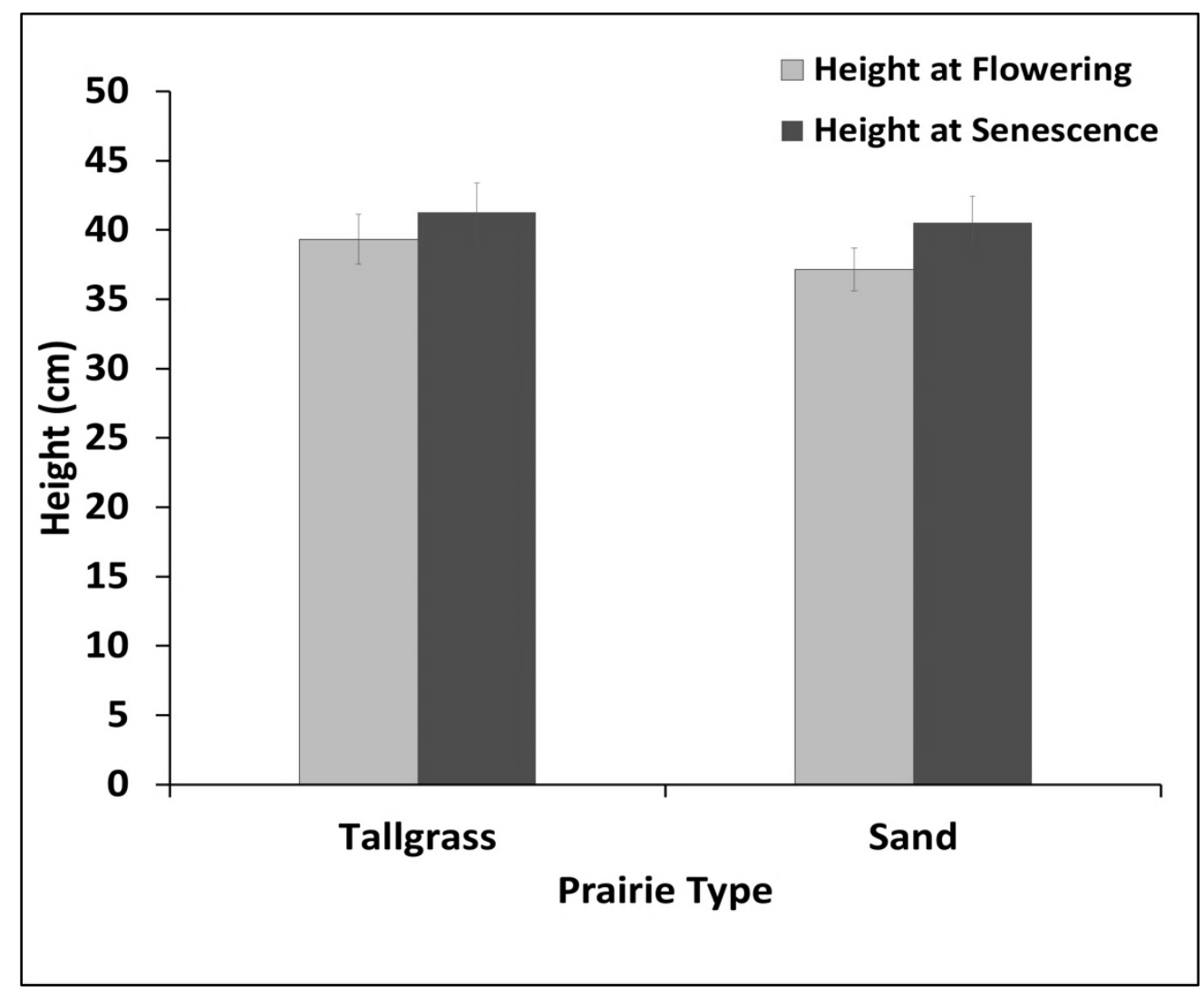

Figure 7. Height at Flowering Day and Senescence by Prairie Type. The mean ( $\pm 1 \mathrm{SE})$ height of C. fasciculata at flowering and senescence by prairie type. The analysis is present on table 7 . 


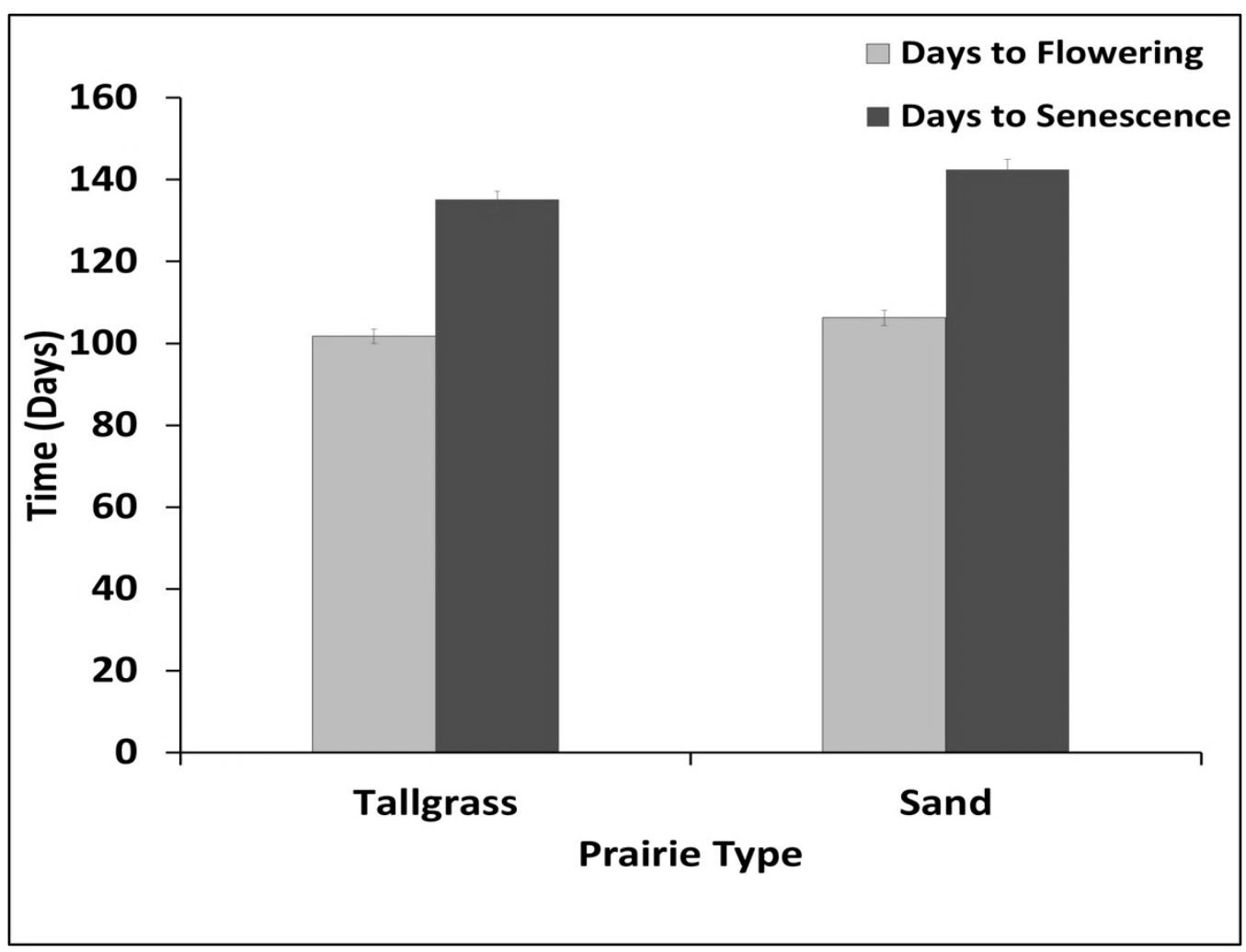

Figure 8. Days to Flowering Day and Senescence by Prairie Type. The mean ( \pm 1 SE) height of C. fasciculata at flowering and senescence by prairie type. The analysis is present on table 7 . 


\section{CHAPTER II: DOES SEED SOURCE OF CHAMAECRISTA FASCICULATA AFFECT ITS SUCCESS IN A RESTORED TALLGRASS PRAIRIE?}

\section{Introduction}

In North America there has been great change and loss of natural areas across the region post-European settlement (Corbett \& Anderson 2006). For example, the encroachment of woody species into grassland ecosystems, the loss of disturbance regimes such as fire, and the fragmentation of habitats (Corbett \& Anderson 2006). In Illinois specifically, the natural landscape has been altered from prairies and savannas to urbanized and modern row crop agriculture land uses. From 1820 to 1970, of the 8.9 million hectares of land that was once prairie, only 1,012 hectares of prairie remain, this is less than $0.1 \%$ of original unaltered landscape (Anderson 1970). Where once there was a continuous habitat, there are now isolated fragments. As natural areas become smaller and more isolated, species richness is expected to become reduced over time for prairies (Diamond 1975; Rowe et al. 2013). Further, fragmentation of natural habitats leads to smaller sized and more isolated populations that can increase genetic drift in remaining populations, increasing the likelihood of inbreeding depression (Harr et al. 2014).

The extensive loss of prairie has resulted in an increased interest in restoration to increase native prairie habitat and biodiversity of native species within this ecosystem. For example, the Illinois Wildlife Action Plan (IWAP), which seeks to restore natural landscapes and coordinate conservation efforts among non-governmental and governmental organizations (Illinois Wildlife Action Plan 2015). Specifically, for plants present within prairie grasslands this requires introducing native species to restored or reconstructed habitats through transplanting or direct 
seeding, the reintroduction of disturbance regimes, and the management of nonnative species (Illinois Wildlife Action Plan 2015). However, the source population that seeds have originated from has been shown to affect the success of individual plant species and communities when introduced to reconstructed or restored habitats (Aavik et al. 2013; Carter \& Blair 2013; Herget et al. 2015). Nonlocal seeds (seeds from different a population and location than a restoration) can respond differently to the same environment relative to local seeds, resulting in asynchronous flowering times and differential resource allocation (Aavik et al. 2013). Different local seed sources have also found to not be equal in their relative success in a restoration. The local seed sources have shown to be more successful (greater biomass production) in relation to other seed sources (Carter \& Blair 20130. Further, cultivated seed sources show less success in relation to local/regional wild seed sources in the presence of other native plant competitors and invasive weeds (Herget et al. 2015). It has been proposed that collecting seeds from seed sources within a 100-mile radius of the proposed restoration/reconstruction will likely result in an increased chance of desired seeds becoming established within a restored or reconstructed site (Smith 2010).

While it has been shown that collecting seeds from local/regional populations may help to establish plant populations in reconstructed and restored habitats, previous research does not take into account that regional seed sources may be from different local types of habitats. Plants that are distributed across a large geographic range can be subject to different selective pressures such as rainfall and soil type across a climatic gradient resulting in local ecotypes from drier regions that exhibit greater fitness in areas of low rainfall (Johnson et al. 2015) or lead to genetic divergence (Gray et al. 2014). However divergent habitats that could result in different ecotypes may also occur on a more local scale that are within a 100-mile radius. In the tallgrass prairie 
region in Illinois, there are over ten prairie types, which are categorized based on variation in glacial history, bedrock, soils, and distribution of plants and animals (White \& Madany 1978).

Plants that occur in a wide geographic range are often present in multiple environmental types (Clausen et al. 1948; Ladd \& Oberle 2005; Lowry \& Willis 2010; Chapter 1). Environments across a species range can vary in both abiotic factors (soil, temperature, moisture, seasonal climate patterns) and biotic factors (competitors, predators, mutualists) (Leimu \& Fischer 2008; Finney et al. 2016; Chapter 1). Differences in these factors can give rise to genetically distinct ecotypes, which are better suited to a particular environment in comparison to other ecotypes of the same species (Lowry \& Willis 2010; Finney et al. 2016).

Tallgrass and sand prairies differ in abiotic characteristics such as soil quality, moisture, and geographic distribution. Vegetation densities also differ between both prairie types, where tallgrass prairies have denser vegetation in comparison to sand prairies. However, depending upon location, some sand prairies have a species composition similar to tallgrass prairie sites with similar soil moisture (Corbett \& Anderson 2001). Furthermore, differences in soil traits can also alter the microbial community that may alter the composition of the plant community (Bever et al. 2010). Few species of flowering native plants are found in both tallgrass prairies and sand prairies (White \& Madany 1978; Chapter 1). Chamaecrista fasciculata, the focus of this field study, is one of the few prairie forbs that occurs in both of these prairie types (White \& Madany 1978).

Biotic factors of the environment can also have a strong effect on the selection of plant traits within prairies (Adhikari \& Russell 2014; Ison et al. 2014; Koch et al. 2014). Invertebrate herbivore damage can reduce plant height, delay flowering and shorten duration of flowering, resulting in lower seed production (Adhikari \& Russell 2014). In addition, invertebrate herbivory 
from specific insects (i.e. aphids) can result in ecotypes that are resistant to specific herbivore effects, showing greater biomass, height, and antibiosis to insect herbivores in comparison to other ecotypes when present in habitats where the invertebrate herbivore is present (Koch et al. 2014). Further, flowering synchronicity and distance between neighbors of the same plant species can influence the frequency of pollinations, where plants that share the same flowering time and are close to each other receive a greater frequency of pollinations (Ison et al. 2014).

For C. fasciculata the focal species of this study, there are a variety of biotic interactions with different organisms beyond pollinators that could lead to differential success in a reconstructed tallgrass prairie. Extrafloral nectaries (EFN) occur at the base of the leaf petioles, producing a nectar reward, with the exception of the first true leaves produced after germination. This nectar is produced in young and mature leaves but not leaves that are senescent (Rios et al. 2008). The plants continue to produce new leaves throughout the growing season, as a result extra floral nectar is produced for most of the growing season (Rios et al. 2008). The EFN's nectar reward attracts a variety of arthropod species, mainly ants (Formicidae). In exchange for the nectar reward, ants provide defense against arthropod herbivores, reducing herbivory (Rutter \& Rausher 2004). Finally, like many legume species $C$. fasciculata has a mutualistic interaction with a species-specific Rhizobium bacterium. The Rhizobium bacteria form nodules within the roots of the plant, fixing atmospheric nitrogen in exchange for photosynthates.

The density and diversity of insect herbivores that target $C$. fasciculata's vegetative structures differ among populations within the tallgrass prairie ecosystem (Rios et al. 2008). Thus, there is the potential for sand and tallgrass populations to differ in their success when interacting with a new community of herbivores. Chamaecrista fasciculata is typically used as a host plant for a variety sulfur butterflies (Pieridae). Their larvae are usually the main insect 
defoliators on the plants vegetative structures within its range (Rios et al. 2008). True weevils (Curculionidae) also pierce holes in leaflets and damage fruit pods (Rios et al. 2008). Fruit pods are damaged either by direct herbivory or by their larvae which burrow into the fruit pods to feed upon the ovules within the pods (personal observation).

Common garden and reciprocal transplant studies can be used to discover if the observed differences of among plant populations in traits when grown in their own vs. novel habitats is due to contrasting selection by specific environmental conditions (Cheplick 2015). Furthermore, these types of studies can provide insights as to how specific aspects of the environment may impact the traits of plants within different environments and the potential for ecotypes to arise in response to differential selection (Galloway \& Fenster 2000; Etterson 2004).

Given the difference in habitat characteristics that $C$. fasciculata is subject to, there is potentially a difference in selective pressure placed upon tallgrass and sand prairie seed source populations. I propose that drought tolerance is an important selecting force imposed upon plants present in a sand prairie habitat. I also propose that tolerance of neighboring competitors for light resources is important in selection upon plants within a tallgrass prairie habitat. Thus, the seeds of plants present within these divergent habitats may exhibit differential responses when introduced to a reconstructed tallgrass prairie. If this is the case, do seeds from tallgrass prairie populations show greater success in a restored tallgrass site in comparison to seeds from sand prairie populations? I predict that tallgrass prairie seed sources will have greater success in the restored tallgrass prairie compared to sand prairie seed sources. I predict tallgrass source populations will receive reduced herbivory, produce greater aboveground and fruit biomass, and have a greater rate of growth (height in $\mathrm{cm}$ ) in relation to sand source populations. To test these predictions, I set out to assess how seed source affects $C$. fasciculata's success within a 
reconstructed tallgrass prairie by performing a common garden experiment using seeds from sand and tallgrass populations. A split-plot design was used to test if $C$. fasciculata tallgrass seed sources were more tolerant of competitors than sand seed sources by imposing a trim treatment, removing other competitors for light resources. Chamaecrista fasciculata was chosen because it has a short-life cycle which enabled estimates of relative success of an individual plant when grown in a tallgrass prairie restoration and $C$. fasciculata is commonly found within contrasting prairie types in Illinois.

\section{Methods}

\section{Study Species}

Chamaecrista fasciculata Michz. (Fabaceae) is an annual plant with a self-compatible breeding system but a mixed mating system (selfing and outcrossing) due to the flowers being mostly pollinated by bumblebees (Bombus spp.) who tend to visit a limited number of flowers on a plant before moving to another (Irwin \& Barneby 1982; Fenster 1991). Pollination typically occurs when the plant receives floral sonication from bumblebees that create vibrations in $C$. fasciculata's flowers via fast contractions of their indirect flight muscles which results in pollen being shed through the anthers pores. Pollen is the only floral reward for pollinators of this species. While pollen does travel between populations under scenarios where there is low flower density, epistasis reduces the fitness of these hybrid offspring limiting successful gene flow between populations (Fenster \& Galloway 2000a; 2000b; Chapter 1).

Chamaecrista fasciculata is a widespread species found in a diversity of habitat types across the species range in North America, within the prairie peninsula region of Illinois and 
Indiana it is commonly found in different types of prairies. Specifically, dry to moist sand prairies and moist tallgrass prairies as well as sandy savannas (Ladd \& Oberle 2005; personal observations). However, for this specific study, I am only including the more divergent habitats sand and tallgrass prairie types to test if habitat source for seeds has an impact on restoration success. Seedlings emerge over a several week period from mid-April through mid-May, flowering begins mid-July and continues through the first frost, and maturing fruits begin to appear in late summer or early autumn after which the plants go into senescence (Galloway \& Fenster 2000; personal observation). Although seeds can remain dormant for one year, this species is not shown to have a long-term seed bank (Baskin \& Baskin 1988).

\section{Seed Source Population}

Chamaecrista fasciculata populations used for seed collection for the field experiment are located in two types of prairie - moist and dry sand prairies, and moist tallgrass prairies (Appendix A). The sand prairies have very sandy soil (>90\% sand) with very low organic matter $(<1.0 \%)$ which results in poor retention of water within the soil. Legumes are the common sand prairie forb along with dominant grasses. Common legumes include: Galega officinallis and Tephrosia virginiana. Common grasses include: Schizachyrium scoparium, Stipa spartea, and Panicum virgatum. The differences in moisture of the dry vs. moist sand prairies is reflected in the vegetation composition. Within moist sandy prairies, further species commonly found include grasses Panicum virgatum and Andropogon gerardii, and forbs Lobelia spicata, Echinacea pallida, and Ratibida pinnata (Appendix B).

Tallgrass prairies have a loam, silt loam or sandy loam soil also known as blacksoil due to high organic matter ( 7\%-10\%). Grass species include: Andropogon gerardi, Schizachyrium scoparium, and Elymus canadensis. In addition, a wide diversity of prairie forbs persists within 
tallgrass prairie sites including: Silphium terebinthinaceum, Silphium laciniatum, and Eryngium yuccifolium (Appendix B).

Seeds for this study were collected by individual plants for each of the populations from a total of 8 populations located in 4 tallgrass prairie sites and 4 sand prairie sites. A majority of the sites are prairie remnants with a couple that are a mix of remnant and restored habitats (Appendix A). Specifically, partly restored sand prairie Scrub Oak was lightly grazed and allowed to recover during the 1940s (Appendix A). Each prairie is managed through the removal of invasive or woody species through a herbicide spray treatment or physical removal. In all prairies the process of fire has also been reintroduced, the tallgrass prairie sites receive a prescribed burn every 2-3 years while the sand prairie sites receive a prescribed burn every 8-10 years (Appendix A). All prescribed burns have been partial burns of the properties in any given year to enable fauna to move to non-burning areas.

\section{Experimental Site}

The site for this study is located in a 15 -year old tallgrass prairie reconstruction that is part of the Franklin Research and Demonstration Farm in Lexington, Illinois $\left(40^{\circ} 63^{\prime} \mathrm{N}\right.$, $\left.88^{\circ} 82^{`} \mathrm{~W}\right)$. Before being converted to a reconstructed tallgrass prairie, this area was used for modern row-crop agriculture (corn and soybean rotation). The site was used for agriculture from the early 1960 's to 2004 , when the site was converted to a tallgrass prairie reconstruction. Previously this location was most likely an oak savanna prairie habitat as the area has rolling hills and a near-by stream (Tim Lindenbaum, reconstruction manager, personal communication). This reconstructed tallgrass prairie including the location for this experiment received a prescribed burn in April 2016 before the June transplanting of seedlings. Further, this prairie is managed through the removal of non-native plant species, the direct seeding of native plant 
species, including C. fasciculata, and the re-introduction of the process of fire. The prescribed burns are conducted each year on different parts of the property, such that all locations are burned once every four years. As many prairie reconstructions are conducted on land that may not have been originally tallgrass prairie, planting a tallgrass prairie plant community in savanna prairie soil, Franklin Farm serves as a good representative of a typical prairie reconstruction in central Illinois where former tallgrass prairies are rarely taken out of crop production.

\section{Experimental Design}

To test the effect of seed source and light competition on plants in this restoration throughout this study, I conducted a common garden experiment in this tallgrass reconstruction using a split-plot design. The split-plot design consisted of six experimental plots (9.6 m x 1.2 $\mathrm{m}$ ), each plot was divided and randomly assigned to trim and non-trim subplots. Seedlings from four sand and four tallgrass prairie populations (seed sources) were transplanted into each subplot using seedlings each from 8 different maternal plants within each seed source ( 8 replicates within the subplots). A trim treatment was imposed to test the impact of lower light competition from the established plants. This treatment will simulate the less dense vegetation of the sand prairie environment (at least for above ground). If tallgrass prairie seed sources are better at tolerating aboveground light competition, then the trimming of above ground vegetation could remove the proposed advantage that tallgrass prairie seed sources have over sand prairie seed sources in a non-trimmed environment (normal vegetation density for tallgrass prairie). Trimming of neighboring vegetation was done using hand-clippers every three to four weeks. Neighboring vegetation was trimmed to $5 \mathrm{~cm}$ in height within and $0.5 \mathrm{~m}$ around the trim treatment subplots. 
Seeds were prepared for the field experiment by scarification using a multi-surface fine grit sandpaper and given a cold moist treatment for two weeks by putting scarified seeds on moist germination paper. These steps are necessary to induce germination in this species. These treated seeds were transplanted into peat pots ( 3 inch $\times 2.5$ inch). The soil used in these pots was a mixture of half-natural prairie soil that is similar to tallgrass soil and half-course sand to create a soil mixture that was not associated to either sand or tallgrass seed collection sites. The soil mixture was steam treated before use to remove impacts of any soil microbes or arthropods. Thus, any Rhizobium interacting with the plants will be from the experimental field site. Once a majority of the seeds had germinated, the seedlings were transplanted into the experimental field plots.

Transplanting took place from June 20, 2016 to June 24, 2016. Seedlings received a small amount of daily watering for the first week after transplant followed by watering every other day for two weeks to acclimate the seedlings to the site. Assessment of relative success of the plants and their local arthropod community began the week after the watering acclimation was finished (July 18, 2016).

\section{Plant Assessment}

To evaluate if the plants from the sand source seeds have lower success growing in this reconstructed prairie compared to the tallgrass source seeds, all plants were assessed throughout the study by measuring height, biomass, and reproductive success. Growth (changes in height) of plants was measured at different stages in their lifecycle (before flowering, during flowering, and after flowering) in order to estimate relative growth of plants nondestructively. Once plants begin to senesce they start to drop their leaflets and fruits thus I frequently collected the biomass to prevent loss of data. Aboveground vegetative and fruit biomass was collected weekly until the 
plants begin to senesce (September 2016 - November 2016). Fruits were collected and placed in a 24-hour freeze treatment to kill any seed predators within the fruits. After collection was complete, the biomass was dried for at least 48 hours at $60{ }^{\circ} \mathrm{C}$ before weighing.

Reproductive success was measured by the total number of fruits produced and the estimated total seeds produced for each plant over the course of the study. Total seed production was estimated by obtaining the mean number of seeds produced per fruit through counting the number of seeds produced by four randomly chosen fruits from each plant. The mean seeds produced per fruit per plant was then multiplied by the total number of fruits produced by the plant to estimate the total seed production per plant. Fruit production assessments were not analyzed as I had a very low sample size of fruits at the end of the study due to low survivorship by rabbits.

To determine if leaf damage on plants from tallgrass prairie source populations is lower than sand prairie source populations in this experiment site, leaf herbivory was measured before and after flowering had begun. During each assessment, three mature leaves with a functioning nectary were selected randomly on each plant. Selected leaves were laid across an index card that was labeled with the plant's identification information and a standardized scale in centimeters. Three photos were then taken with a digital camera of the three selected leaves per plant. Afterwards, the average total leaf area and average total leaf area lost to herbivory of leaves for each plant was estimated from the digital images using the NIH imaging software, imageJ (https://imagej.nih.gov/ij/). If excessive herbivory had taken place (all leaves had been removed from the stem of a plant or if the plant is uprooted) the plant's identification information and date the excessive herbivory had taken place was recorded. 
To evaluate if seed predation was lower in the tallgrass seed source plants, seed predation was assessed using fruits collected to assess fruit biomass and seed production. When the fruits were assessed for seed production each fruit was inspected for seed predation. If seed predation had taken place either frass, arthropod larvae, or both will be present within the fruit. Any larvae found in fruit were collected and added to the arthropod survey data (Appendix C). Fruits impacted by seed predation were opened to assess how many seed are still present within the fruit and how many seeds the fruit would have produced. However, seed predator assessments were not analyzed as I had a very low sample size of fruits at the end of the study and analyzing seed predation was not possible.

To determine if the extrafloral nectar (EFN) production of tallgrass and sand prairie seed sources differ, nectar volume of individual plants was measured over a 24-hour period. I used a modification of the method used by Rios et al. (2018). First, standing extrafloral nectar was removed using filter paper (Whatman \#1 filter paper) from the five nectaries in the highest vertical position on each plant. Sampled nectaries are then covered with a strip of aluminum foil to deter nectar foragers. 24 hours later, all newly accumulated extrafloral nectar from the five nectaries is collected onto a single slip of filter paper. The area of the nectar spot is outlined in pencil, placed into a labeled coin envelope, and taken to the lab for measurement. The volume of nectar collected from the five EFNs is proportional to the area of the nectar spot. This area is then estimated from a digital image taken next to a $5 \mathrm{~cm}$ standardized scale using the NIH computer program, imageJ (https://imagej.nih.gov/ij/). 


\section{Arthropod Assessment}

To assess the arthropod community within the field site two surveys were conducted. The first survey was done before flowering (July 24, 2016) and the second survey was conducted once flowering had begun (August 16, 2016). Each plant was searched for ants, herbivorous insects, other arthropods, and lepidopteran eggs. Captured arthropods were then incapacitated using a kill jar and placed into individual glassine envelopes. All captured arthropods were then taken back to the lab to be identified and processed. Hard-bodied arthropods were then pinned and soft-bodied arthropods were placed into individual vials of ethyl alcohol for preservation.

\section{Statistical Analyses}

To determine if seeds from tallgrass populations showed greater success in a reconstructed tallgrass prairie in comparison to seeds from sand prairie populations, I used a split-plot with a nested factorial analysis of variance (ANOVA). The whole plot effects were trim treatment, block and their interaction. The sub-plot effects were prairie type, population nested within prairie type and their interactions with other effects. Prairie type, trim treatment, and their interactions were considered fixed effects. Block and population and interactions with these effects were treated as random effects. The GLM procedure in SAS version 9.4 statistical package was used for these analyses (SAS 2012).

To test if sand populations had lower growth rate (height in $\mathrm{cm}$ ) in comparison to tallgrass a multivariate analysis of variance (MANOVA) was used with the split-plot design. As height measured on the same plants overtime is not independent, I used the MANOVA approach. Height was square root transformed to meet the assumptions of ANOVA. 
Assessment of aboveground and fruit biomass of the plants was determined by multivariate analysis of variance (MANOVA). A MANOVA was used as it allowed me to jointly test the response variables as they are not independent. Furthermore, differences that exist among populations or other treatments many not be a feature of any one of the response variables alone but the combination of all variables. Aboveground and fruit biomass was square root transformed to meet the assumptions.

To test if tallgrass populations receive reduced herbivory in relation to sand populations a split-plot ANOVA was used. Estimate of herbivory (leaf area lost to herbivory/total leaf area sampled=relative leaf area lost to herbivory) were natural log and square root transformed respectively to meet assumptions. Further, to test if tallgrass populations differed in their volume of extrafloral nectar in comparison to sand populations a split-plot ANOVA was used. Nectar production was square root transformed for population for this analysis.

However, due to low sample size, growth rate, biomass, nectar production, and herbivory analyses used a reduced model of the split-plot analysis. This reduced model did not include population nested within prairie type and the interactions with this effect.

\section{Results}

The trim treatment, prairie type, and their interaction did not explain the differences in the rate of growth of $C$. fasciculata (Fig. 9; Table 9). The reduction in numbers of plants due to high mortality before the height measurements were taken on August $16\left(\mathrm{~N}_{\text {total }}=228, \mathrm{~N}_{\text {prairie type }}\right.$

$=\geq 3$ per subplot, $\mathrm{N}_{\text {prairie type }}$ trim treatments $=\geq 3$ per subplot $)$ and October $15\left(\mathrm{~N}_{\text {total }}=123, \mathrm{~N}_{\text {prairie }}\right.$ 
type $=\geq 2$ per subplot, $\mathrm{N}_{\text {prairie type*trim treatments }}=\geq 2$ per subplot) may have limited my ability to detect the effect of these treatments and their interaction.

The trim treatment, prairie type, and their interaction also did not explain the differences in the aboveground vegetative biomass and fruit biomass of the plants (Fig. 10; Fig. 11; Table 9). The reduced number of plants surviving to have their biomass harvested (aboveground biomass $\mathrm{N}_{\text {total }}=123, \mathrm{~N}_{\text {prairie type }}=\geq 2$ per subplot, $\mathrm{N}_{\text {prairie type } * \text { trim treatments }}=\geq 2$ per subplot and fruit biomass $\mathrm{N}_{\text {total }}=83, \mathrm{~N}_{\text {prairie type }}=\geq 1$ per subplot, $\mathrm{N}_{\text {prairie type }}{ }^{*}$ trim treatments $=\geq 1$ per subplot) may have limited my ability to detect the impact of the treatments on C. fasciculata.

Herbivory (not by the rabbits) of the plants was significantly impacted by the trim treatment for both the first and second measurements (Table 12; Table 13). Further, the interaction of trim treatment and block significantly contributed to the relative leaf area lost to herbivory in both measurements (Table 12; Table 13). In the first measurement, plants did not differ in the relative leaf area lost between the trim treatments (Fig. 13). However, plants present where no trim treatment had been imposed received greater relative leaf area lost to herbivory than plants present were a trim treatment was conducted in the second measurement (Fig. 14). Seed source and the interactions of trim treatment with seed source and experimental block with seed source did not significantly impact herbivory (Table 12; Table 13). Failure to detect significance in the later measurements of relative leaf area lost to herbivory may be due to poor sample size $\left(\mathrm{N}_{\text {total }}=209, \mathrm{~N}_{\text {prairie type }}=\geq 3\right.$ per subplot, $\mathrm{N}_{\text {prairie type } * \text { trim treatments }}=\geq 3$ per subplot $)$.

The trim treatment, prairie type, and their interaction did not significantly affect the extrafloral nectar production of the plants (Fig 12; Table 9). Further, all interactions did not have a significant effect on extrafloral nectar production (Table 9). 
While the initial sample size of our study was created so there were 8 replicate plants per population per experimental plot per trimming treatment, the combination of low survivorship and substantial mortality due to the unexpected rabbit herbivory greatly reducing my sample size for all aspect of this study. From the first field measurements taken on June 15 to the last taken November 1 saw sample sizes decreased from $N_{\text {total }}=791, N_{\text {prairie type }}=8$ per subplot, $N_{\text {prairie }}$ type*trim treatments $=8$ per subplot to $\mathrm{N}_{\text {total }}=123, \mathrm{~N}_{\text {prairie type }}=\geq 2$ per subplot, $\mathrm{N}_{\text {prairie type }}{ }^{*}$ trim treatments $=$ $\geq 2$ per subplot. This limited my ability to detect the effect of the treatments and their interactions particularity data that was collected on later dates in the study.

A diverse group of arthropods was collected from the plants during the surveys conducted. Twenty-three different insect species from eight different insect families were observed and captured on C. fasciculata (Appendix C). Ants (Formicidae) were the most abundant family of individual insects collected ( 21.5\%), consisting of eight different species, the most abundant being the little black ant (Monomorium minimum). Syrphid flies (Syrphidae) and long-tonged bees (Apidae) were the second and third most abundant families respectively (Appendix C). Two different syrphid fly species were collected, Allograpta obliqua and Helophilus fasciatus, representing $\sim 20.8 \%$ of the individual insects collected. Further, four different long-tonged bee species were collected making up around $17.04 \%$ of individuals collected. These species include the honeybee (Apis mellifera), eastern bumblebee (Bombus impatiens), walsh's digger (Anthrophora walshii), and the long horn bee (Svastra atripes) Other insect families collected include sulfur butterflies (Pieridae), katydids (Tettigonidae), primitive weevils (Brentidae), grasshoppers (Acrididae), and stingbugs (Pentatomidae). 


\section{Discussion}

Restoration of the tallgrass prairie ecosystem has been a focus in Illinois due to the alteration of the natural landscape to suit urbanization and modern row-crop agriculture (Corbert \& Anderson 2006). Evaluating how seeds from differing habitats respond to restored tallgrass sites helps site managers to select which seed sources are used for a restoration to introduce native species to a site. My results found no evidence of tallgrass populations showing any greater success in a reconstructed tallgrass prairie in comparison to sand prairie populations. Further, the growth rate, biomass, and extrafloral nectar production of $C$. fasciculata populations were not significantly affected by the imposed treatments in this study.

However, plants in the trim vs. no trim treatment were found to differ from each other in relative leaf area lost to herbivory. Specifically, plants did exhibit greater leaf herbivory with no trimming of the surrounding vegetation. This greater herbivory could be due to the height of neighboring vegetation, where if $C$. fasciculata is surrounded by vegetation that is equal or greater in height which provides greater accessibility of $C$. fasciculata to arthropod herbivores from adjacent plants. Tall neighboring vegetation has been considered a factor that allows both beneficial and detrimental arthropods to access the plant in previous studies involving $C$. fasciculata (Rios et al. 2008). Further, areas within grasslands that have tall vegetation have shown to support more arthropod species in comparison to areas with shorter vegetation (Pöyry

et al. 2006). Thus, there could be a greater number of herbivorous arthropods present in sub-plots of the study where no trimming was imposed. However, it is important to remember that given the small sample size of my results it is difficult to make definitive conclusions.

While C. fasciculata's seed source did not impact its relative success in most measured variables, there are examples where the selection of a specific seed source can impact a plant 
species' response to a restored grassland (Bischoff et al., 2006; Carter \& Blair, 2012; Burcharova et al. 2016). Both forb and grass species have shown evidence of local adaptation, where local seed sources exhibit greater success than non-local seed sources (Bischoff et al. 2006;

Burcharova et al. 2016). Local seed sources have also been shown to exhibit greater competitive ability than their non-local counterparts (Bischoff et al. 2006). Further, local seed sources have also shown to have greater flower and biomass production in relation to non-local seed sources (Burcharova et al. 2016). In addition, the interaction of a sites geographical position and the seed source can affect introduced plant species survival within a restoration (Carter \& Blair 2012). However, in all said studies these results were found in plant species across a large geographic scale ( $\geq 100$ miles). When assessing seed source on a local scale, the evidence of differential responses in non-local vs. local seed sources is less consistent (Bischoff et al. 2006; Carter \& Blair 2012; Burcharova et al. 2017). There is evidence of genetic population differentiation of local seed sources from contrasting habitat types resulting in differential responses to habitats they are introduced (Bischoff et al. 2006). Furthermore, plant species have shown to have a singular seed source that is more successful than all other non-local and local seed sources of said species, suggesting no adaptation to a particular habitat or range (Bischoff et al. 2006). In other cases, local seed sources of forb and grass species have shown no evidence of consistent advantages, such as survival, in relation to non-local seed sources (Carter \& Blair 2012). Further, there is evidence maladaptation in local seed sources, where non-local seeds are more successful in relation to their local counterparts (Burcharova et al. 2017).

With the seeding or transplanting of native plant species to a reconstructed or restored tallgrass prairie, it is important to understand if seeds from the same species differ in their response to this new habitat as the evidence for differential success in seed sources varies. Such 
information would be helpful for a site manager, as they could predict where seeds should be collected to increase the success of establishment and mitigate against future environmental changes. While I observed no significant difference in the relative success of sand and tallgrass populations of C. fasciculata in a restored tallgrass prairie there are ecotypes of this species that bear tradeoffs between aboveground biomass and reproductive allocation in the wet marshlands and dry uplands of South Dakota (Finney et al. 2016). Still, there are many opportunities to understand how $C$. fasciculata and other plant species differ on a local habitat scale, with a focus towards aiding site managers in choosing a successful seed set. Future research should continue the study of local plant ecotypes and their differences in response to a diversity of habitats. 


\section{References}

Aavik T, Bosshard D, Edwards PJ, Holderegger R, Billeter R (2013) Fitness in naturally occurring and restored populations of a grassland plant Lychnis flos-cuculi in a Swiss agricultural landscape. Restoration Ecology 22:98-106

Abdala-Roberts L, Marquis RJ (2007) Test of local adaptation to biotic interactions and soil abiotic conditions in the ant-tended Chamaecrista fasciculata (Fabaceae). Oecologia 154:315-326.

Adhikari S, Russell FL (2014) Effects of apical meristem mining on plant fitness, architecture, and flowering phenology in Cirsium altissimum (Asteraceae). American Journal of Botany 101:2079-2087.

Anderson RC (1970) Prairies in the prairie state. Transactions of the Illinois State Academy of Science 63:214-221.

Aspinwall MJ, Lowry DB, Taylor SH, Juenger TE, Hawkes CV, Johnson M-VV, Kiniry JR, Fay PA (2013) Genotypic variation in traits linked to climate and aboveground productivity in a widespread C4 grass: evidence for a functional trait syndrome. New Phytologist 199:966980.

Baer SG, Gibson DJ, Gustafson DJ, Benscoter AM, Reed LK, Campbell RE, Wodika BR (2013) No effect of seed source on multiple aspects of ecosystem functioning during ecological restoration: Cultivars compared to local ecotypes of dominant grasses. Evolutionary Applications 7:323-335.

Baskin CC, Baskin JM (1988) Germination ecophysiology of herbaceous plant species in a temperate region. American Journal of Botany 75:286-305. 
Bever JD, Dickie IA, Facelli E, Facelli JM, Klironomos J, Moora M, Rillig MC, Stock WD, Tibbett M, Zobel M (2010) Rooting theories of plant community ecology in microbial interactions. Trends in Ecology and Evolution 25:468-478.

Bischoff A, Crémieux L, Smilauerova M, Lawson CS, Mortimer SR, Dolezal J, Müller-Schärer H (2006) Detecting local adaptation in widespread grassland species? The importance of scale and local plant community. Journal of Ecology 94:1130-1142

Bowles ML, Mcbride JL, Bell TJ (2015) Long-term processes affecting restoration and viability of the federal threatened mead's milkweed (Asclepias meadii). Ecosphere.6:1-22.

Bucharova A, Michalski S, Hermann J, Heveling K, Durka W, Hölzel N, Bossdorf O (2016) Genetic differentiation and regional adaptation among seed origins used for grassland restoration: Lessons from a multispecies transplant experiment. Journal of Applied Ecology $54: 127-136$.

Bucharova A, Durka W, Hölzel N, Kollmann J, Michalski S, Bossdorf O (2017) Are local plants the best for ecosystem restoration? It depends on how you analyze the data. Ecology and Evolution 7:10683-10689.

Carter DL, Blair JM (2012) Seed source affects establishment and survival for three grassland species sown into reciprocal common gardens. Ecosphere 3:1-10.

Carter DL, Blair JM (2013) Seed source has variable effects on species, communities, and ecosystem properties in grassland restorations. Ecosphere 4:1-16.

Cheplick GP (2015) Approaches to Plant Evolutionary Ecology. Oxford University Press, Oxford 
Clausen J, Keck DD, and Heisey WM (1948) Experimental studies on the nature of species. III. Environmental responses of climatic races of Achillea. Carnegie Institute of Washington. 581.

Corbett EA, Anderson RC (2001) Patterns of prairie plant species in Illinois' landscape. Proceedings of the Seventeenth North American Prairie Conference. North Iowa Area Community College, Mason City, Iowa.

Corbett EA, Anderson RC (2006) Landscape analysis of Illinois and Wisconsin remnant prairies. The Journal of the Torrey Botanical Society 133:267-279.

Diamond JM (1975) The island dilemma: Lessons of modern biogeographic studies for the design of natural reserves. Biological Conservation 7:129-146.

Endler JA (1986) Natural selection in the wild. Monographs in Population Biology. no. 21. Princeton University Press, Princeton, New Jersey.

Espeland EK. Emery NC, Mercer KL, Woolbright SA, Kettenring KM, Gepts P, Etterson JR (2016) Evolution of plant materials for ecological restoration: insights from the applied and basic literature. Journal of Applied Ecology 54:102-115.

Etterson JR (2004) Evolutionary potential of Chamaecrista fasciculata in relation to climate change. I. clinal patterns of selection along an environmental gradient in the great plains. Evolution 58:1446-1456.

Evers RA (1955) Hill prairies of Illinois. Bull. 111. Natural History Survey 26:367-466.

Fenster CB (1991) Gene flow in Chamaecrista fasciculata (Leguminosae). I. Gene dispersal. Evolution 45:308-409.

Fenster CB, Galloway LF (2000a) Inbreeding and outbreeding depression in natural populations of Chamaecrista fasciculata (Fabaceae). Conservation Biology 14:1406-1412. 
Fenster CB, Galloway LF (2000b) Population differentiation in an annual legume: genetic architecture. Evolution 54:1157-1172.

Fenster CB, Vekemans X, Hardy OJ (2003) Quantifying gene flow from spatial genetic structure data in a metapopulation of Chamaecrista fasciculata (Leguminosae). Evolution 57:9951007.

Finney TE, Gedan KB, Fenster CB (2016) Allocation patterns contribute to the distributional limits of a flood tolerant ecotype of Chamaecrista fasciculata. Aquatic Botany 134:31-38.

Gallagher MK, Wagenius S (2016) Seed source impacts germination and early establishment of dominant grasses in prairie restorations. Journal of Applied Ecology 53:251-263.

Galloway LF, Fenster CB (2000) Population differentiation in an annual legume: local adaptation. Evolution 54:1173-1181.

Galloway LF, Fenster CB (2001) Nuclear and cytoplasmic contributions to intraspecific divergence in an annual legume. Evolution 55:488-497.

Gleason HA, Cronquist A (1964) The natural geography of plants. Columbia University Press, New York, New York.

Gray MM, Amand PS, Bello NM, Galliart MB, Knapp M., Garrett KA, Morgan TJ, Baer SG, Maricle BR, Akhunov ED, Johnson LC (2014) Ecotypes of an ecologically dominant prairie grass (Andropogon gerardii) exhibit genetic divergence across the U.S. Midwest grasslands' environmental gradient. Molecular Ecology 23:6011-6028.

Harr RN, Wright Morton, L, Rusk SR, Engle DM, Miller JR, Debinski D (2014) Landowners' perceptions of risk in grassland management: woody plant encroachment and prescribed fire. Ecology and Society 19:41-54 
Herget M. Hufford K, Mummey D, Mealor B, Shreading L (2015) Effects of competition with Bromus tectorum on early establishment of Poa secunda accessions: can seed source impact restoration success?. Restoration Ecology 23:277-283.

Hobbs RJ, Cramer VA (2008) Restoration ecology: Interventionist approaches for restoring and maintaining ecosystem function in the face of rapid environmental change. Annual Review of Environment and Resources 33:39-61.

Hobbs RJ, Hallett LM, Ehrlich PR, Mooney HA (2011) Intervention ecology: Applying ecological science in the twenty-first century. BioScience 61:442-450.

Irwin HS, Barneby RC (1982) The American Cassiinae: A synoptical revision of Leguminosae tribe Cassieae subtribe Cassiinae in the new world. Kew Bulletin 39: 636-664.

Ison JL, Wagenius S, Reitz D, Ashley MV (2014) Mating between Echinacea angustifolia (Asteraceae) individuals increases with their flowering synchrony and spatial proximity. American Journal of Botany 101:180-189.

Jackson RD, Paine LK, Woodis JE (2010) Persistence of native C4 grasses under high-intensity, short-duration summer bison grazing in the eastern tallgrass prairie. Restoration Ecology. $18: 65-73$.

Johnson LC, Olsen JT, Tetreault H, Delacruz A, Bryant J, Morgan TJ, Knapp M, Bello NM, Baer SG, Maricle BR (2015) Intraspecific variation of a dominant grass and local adaptation in reciprocal garden communities along a US Great Plains' precipitation gradient: implications for grassland restoration with climate change. Evolutionary Applications 8:705723. 
Johnson NC, Wilson GWT, Bowker MA, Wilson JA, Miller RM (2010) Resource limitation is a driver of local adaptation in mycorrhizal symbioses. Proceedings of the National Academy of Sciences 107:2093-2098.

Kim E, and Donohue K (2013) Local adaptation and plasticity of Erysimum capitatumto altitude: Its implications for responses to climate change. Journal of Ecology 101:796-805.

Kindell CE, Winn AA, Miller TE (1996) The effects of surrounding vegetation and transplant age on the detection of local adaptation in the perennial grass Aristida stricta. Journal of Ecology 84:745-754.

Koch KG, Bradshaw JD, Heng-Moss TM, Sarath G (2014) Categories of resistance to greenbug and yellow sugarcane aphid (Hemiptera: Aphididae) in three tetraploid switchgrass populations. BioEnergy Research 7:909-918.

Ladd DM, Oberle F (2005) Tallgrass prairie wildflowers: a field guide to common wildflowers and plants of the prairie Midwest. Falcon Guilford, Connecticut.

Lauterbach D, Ristow M, Gemeinholzer B (2011) Population genetics and fitness in fragmented populations of the dioecious and endangered Silene otites (Caryophyllaceae). Plant Systematics and Evolution 298:155-164.

Leimu R, Fischer M (2008) A meta-analysis of local adaptation in plants. PLoS ONE 3: e4010. Lindborg R, Eriksson O (2004) Historical landscape connectivity affects present plant species diversity. Ecology 85:1840-1845.

Lowry D, Willis J (2010) A widespread chromosomal inversion polymorphism contributes to a major life-history transition, local adaptation, and reproductive isolation. PLoS Biology 8: e1000500. 
Lowry DB, Behrman KD, Grabowski P, Morris GP, Kiniry JR, Juenger TE (2014) Adaptations between ecotypes and along environmental gradients in Panicum virgatum. The American Naturalist 183:682-692.

Mannouris C, Byers D (2013) The impact of habitat fragmentation on fitness-related traits in a native prairie plant, Chamaecrista fasciculata (Fabaceae). Biological Journal of the Linnean Society 108:55-67.

Rios RS, Marquis RJ, Flunker JC (2008) Population variation in plant traits associated with ant attraction and herbivory in Chamaecrista fasciculata (Fabaceae). Oecologia 156:577-588.

Robertson KR, Schwartz MW, Olson JW, Dunphy BK, Clarke HD (1995) Fifty years of change in Illinois hill prairies. Erigenia 14:41- 52.

Rowe HI, Fargione J, Holland JD (2013) Prairie Restorations can protect remnant tallgrass prairie plant communities. The American Midland Naturalist. 170:26-38.

Rutter MT, Rausher MD (2004) Natural selection on extrafloral nectar production in Chamaecrista fasciculata: the costs and benefits of a mutualism trait. Evolution 58:26572668.

SAS (2012) SAS version 9.4. SAS Institute, Cary, North Carolina

Smith DD (2010) The Tallgrass Prairie Center guide to prairie restoration in the Upper Midwest. University of Iowa Press, Iowa City, Iowa.

White J, Madany MH (1978) Classification of natural communities in Illinois. Illinois Natural Areas Inventory Technical Report. Volume 1: Survey Methods and Results 1:310-405. 


\section{Tables}

Table 9. Growth Rate Split-Plot MANOVA Analysis. Results of the MANOVA assessing the 26, June to 16, August and the 16, August to 15, October height measurements of the plants. The data was square root transformed to meet the assumptions of a MANOVA. Canonical correlation coefficient results from both height measurements are also displayed.

\begin{tabular}{|c|c|c|c|c|c|c|}
\hline Source & DF & $\begin{array}{l}\text { Wilks' } \\
\text { lambda }\end{array}$ & $\begin{array}{l}\text { F } \\
\text { ratio }\end{array}$ & $\begin{array}{l}\text { Probability } \\
\text { Value }\end{array}$ & $\begin{array}{l}\text { June 26 - } \\
\text { August } 16\end{array}$ & $\begin{array}{l}\text { August } 16- \\
\text { October } 15\end{array}$ \\
\hline Trim Treatment & 2,3 & 0.9218 & 0.13 & 0.8852 & -0.6470 & 1.4267 \\
\hline Block & 10,6 & 0.3108 & 0.48 & 0.8567 & 1.1794 & -0.4139 \\
\hline Trim Treatment*Block & 8,44 & 0.7206 & 0.98 & 0.4649 & 0.9937 & 0.3974 \\
\hline Prairie Type & 2,22 & 0.9689 & 0.35 & 0.7069 & 1.1393 & 0.1258 \\
\hline Prairie Type* Trim Treatment & 2,22 & 0.9832 & 0.19 & 0.8307 & 0.1350 & 0.8644 \\
\hline Block*Prairie Type & 8,44 & 0.7978 & 0.66 & 0.7252 & 1.1690 & -0.0251 \\
\hline Trim Treatment*Block*Prairie Type & 4,23 & 0.6972 & 0.42 & 0.5728 & -0.0732 & 0.8828 \\
\hline Residual & 18,191 & & & & & \\
\hline
\end{tabular}


Table 10. Biomass Split-Plot MANOVA Analysis. Results from the MANOVA assessing the aboveground and fruit biomass. The data was natural log transformed to meet the assumptions of a MANOVA. Canonical correlation coefficient results from aboveground and fruit biomass are also displayed.

\begin{tabular}{|c|c|c|c|c|c|c|}
\hline Source & DF & $\begin{array}{l}\text { Wilks' } \\
\text { lambda }\end{array}$ & F ratio & $\begin{array}{l}\text { Probability } \\
\text { Value }\end{array}$ & $\begin{array}{l}\text { Aboveground } \\
\text { Biomass }\end{array}$ & Fruit Biomass \\
\hline Trim Treatment & 2,4 & 0.6140 & 1.26 & 0.3770 & 0.6932 & 1.5257 \\
\hline Block & 10,8 & 0.1918 & 1.03 & 0.4948 & 0.5289 & 1.6862 \\
\hline Trim Treatment*Block & 10,122 & 0.8874 & 0.74 & 0.6873 & 1.0682 & -0.6234 \\
\hline Prairie Type & 2,60 & 0.5926 & 0.33 & 0.7180 & 0.7567 & 0.3788 \\
\hline Prairie Type* Trim Treatment & 2,60 & 0.9831 & 0.51 & 0.6010 & -0.8826 & 0.9117 \\
\hline Block*Prairie Type & 8,120 & 0.9279 & 0.57 & 0.7995 & 1.0886 & -0.5050 \\
\hline Trim Treatment*Block*Prairie Type & 4,122 & 0.6972 & 0.62 & 0.4511 & 0.9056 & -0.6716 \\
\hline
\end{tabular}

Residual

18, 795 
Table 11. Nectar Production Split-Plot ANOVA Analysis. Results from the ANOVA assessing the nectar production of $C$. fasciculata. The data was square root transformed to meet the assumptions of a split-plot ANOVA.

\begin{tabular}{|c|c|c|c|c|}
\hline Source & DF & Type III SS & F Ratio & $\begin{array}{l}\text { Probability } \\
\text { Value }\end{array}$ \\
\hline Trim Treatment & 1 & 0.0009 & 0.10 & 0.7557 \\
\hline Block & 5 & 0.0987 & 2.05 & 0.0695 \\
\hline Trim Treatment*Block & 5 & 0.0726 & 1.51 & 0.1846 \\
\hline Prairie Type & 1 & 0.0001 & 0.01 & 0.9030 \\
\hline Prairie Type* Trim Treatment $^{*}$ & 1 & 0.0018 & 0.19 & 0.6624 \\
\hline Block*Prairie Type & 5 & 0.0276 & 0.57 & 0.7199 \\
\hline Trim Treatment*Block*Prairie Type & 5 & 0.0026 & 0.61 & 0.6910 \\
\hline Residual & 762 & 7.3361 & & \\
\hline
\end{tabular}


Table 12. Relative Leaf Area Lost to Herbivory, Measurement 1, Split-Plot ANOVA Analysis.

First measurement (July 24-25) results of the ANOVA assessing the relative leaf area lost to herbivory. The data was square root transformed to meet the assumptions of a split-plot ANOVA.

\begin{tabular}{|c|c|c|c|c|}
\hline Source & DF & Type III & F Ratio & Probability \\
\hline & & SS & & Value \\
\hline Trim Treatment & 1 & 2.2680 & 2733.19 & $<0.0001$ \\
\hline Block & 5 & 1.2303 & 306.16 & $<0.0001$ \\
\hline Trim Treatment*Block & 5 & 3.0995 & 720.25 & $<0.0001$ \\
\hline Prairie Type & 1 & 0.0006 & 0.41 & 0.5205 \\
\hline Prairie Type* Trim Treatment & 1 & 0.0015 & 1.94 & 0.1642 \\
\hline Block*Prairie Type & 5 & 0.0051 & 1.18 & 0.3162 \\
\hline Trim Treatment*Block*Prairie & 5 & 0.0026 & 0.61 & 0.6910 \\
\hline Type & & & & \\
\hline Residual & 774 & 7.5511 & & \\
\hline
\end{tabular}


Table 13. Relative Leaf Area Lost to Herbivory, Measurement 2, Split-Plot ANOVA Analysis. Second measurement (August 30 - September 1) results of the ANOVA assessing the relative leaf area lost to herbivory. The data was square root transformed to meet the assumptions of a split-plot ANOVA.

\begin{tabular}{|c|c|c|c|c|}
\hline Source & DF & $\begin{array}{l}\text { Type III } \\
\text { SS }\end{array}$ & F Ratio & $\begin{array}{l}\text { Probability } \\
\text { Value }\end{array}$ \\
\hline Trim Treatment & 1 & 1.1001 & 972.11 & $<0.0001$ \\
\hline Block & 5 & 0.0351 & 6.20 & $<0.0001$ \\
\hline Trim Treatment*Block & 5 & 0.0938 & 16.59 & $<0.0001$ \\
\hline Prairie Type & 1 & 0.0022 & 1.93 & 0.1666 \\
\hline Prairie Type* Trim Treatment & 1 & 0.0029 & 2.65 & 0.1052 \\
\hline Block*Prairie Type & 5 & 0.0077 & 1.36 & 0.2411 \\
\hline Trim Treatment*Block*Prairie & 5 & 0.0022 & 0.40 & 0.8499 \\
\hline \multicolumn{5}{|l|}{ Type } \\
\hline Residual & 207 & 1.9201 & & \\
\hline
\end{tabular}




\section{Figures}

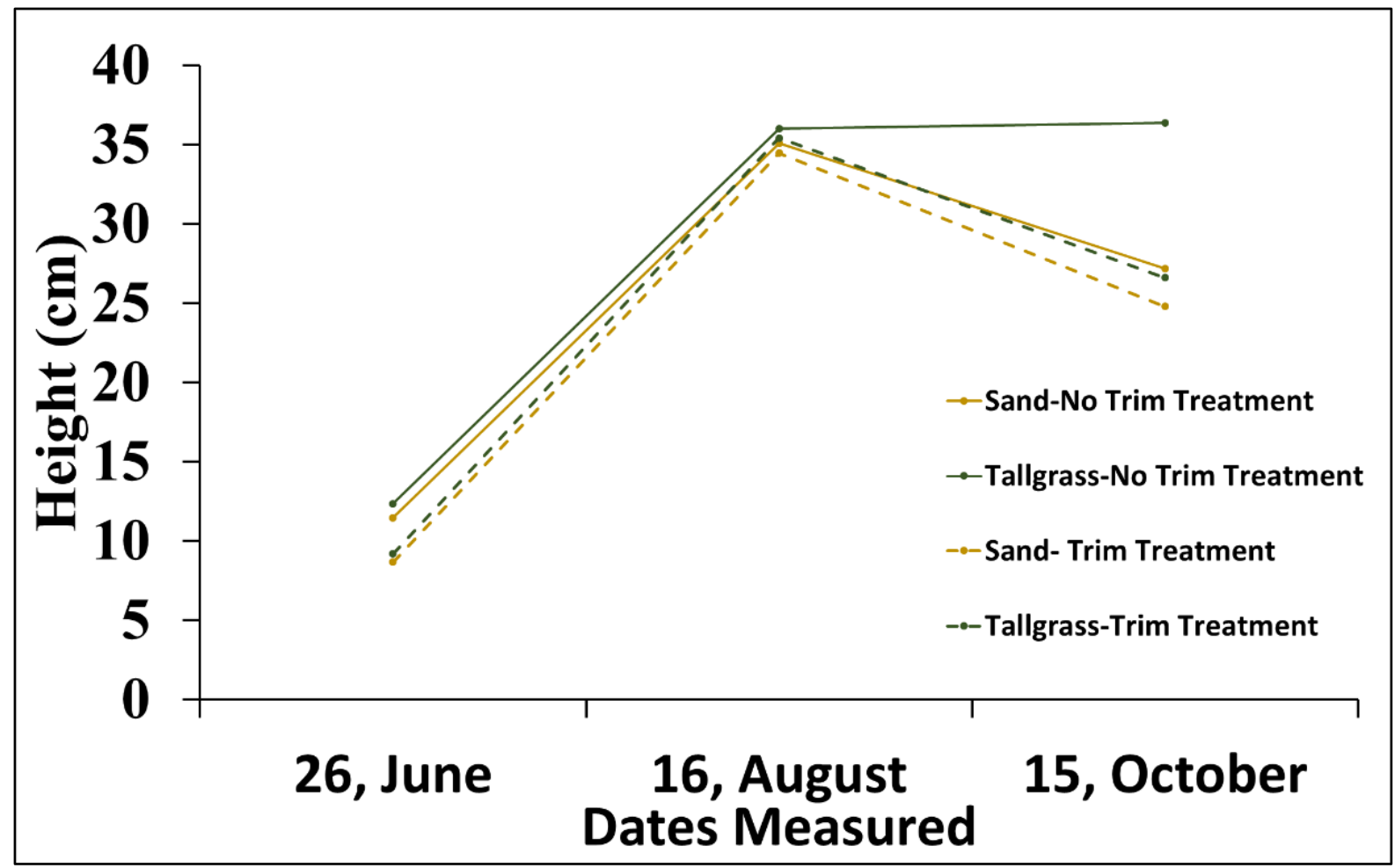

Figure 9. Field Study Mean Height. The mean height of $C$. fasciculata based on trim treatment and seed source taken on 26, June and 16, August and 15, October. Analysis is present in table 8 . 


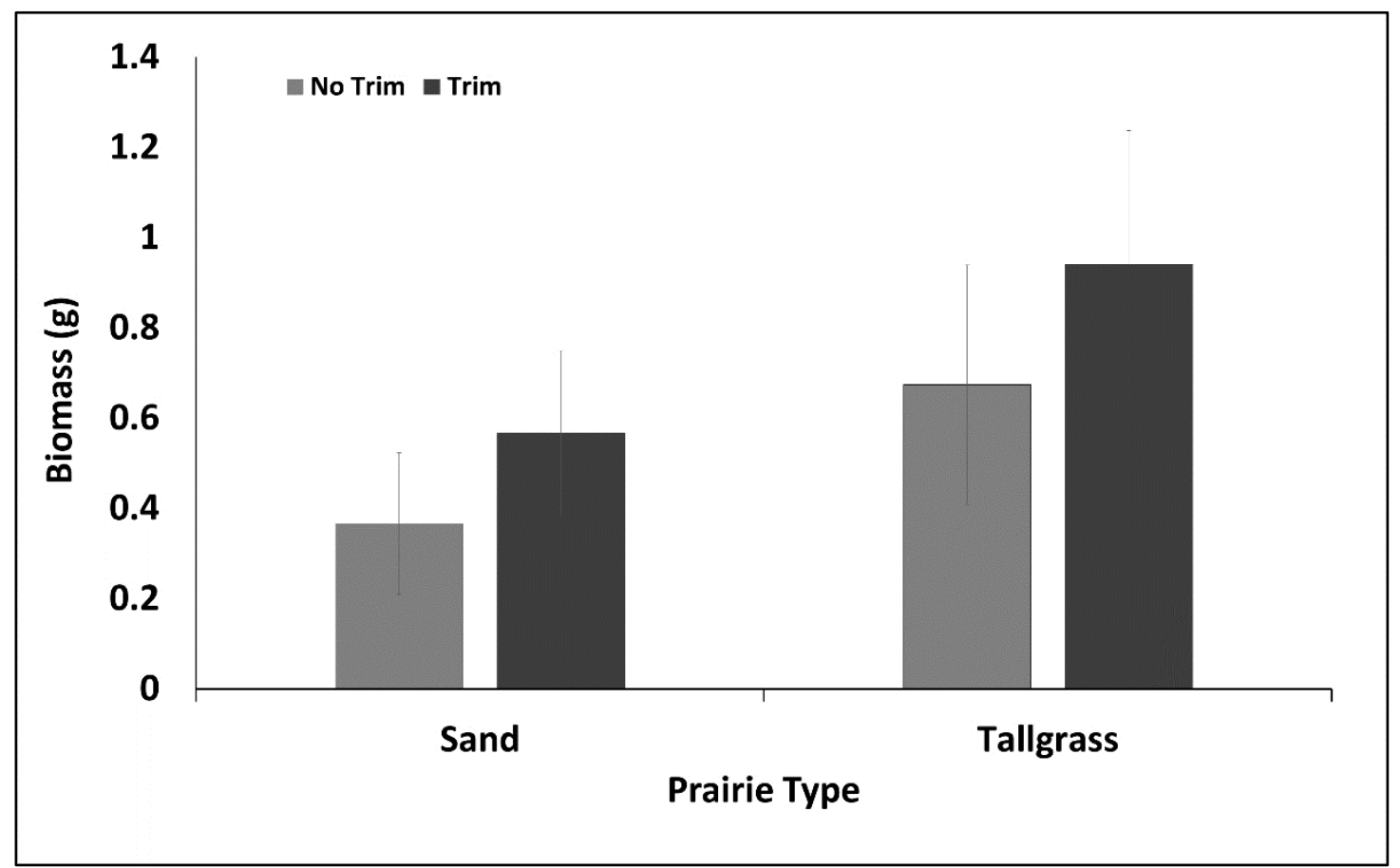

Figure 10. Field Aboveground Biomass. The mean ( $\pm 1 \mathrm{SE})$ aboveground vegetative biomass of C. fasciculata seed sources based on their trim treatment. The analysis is presented in table 9. 


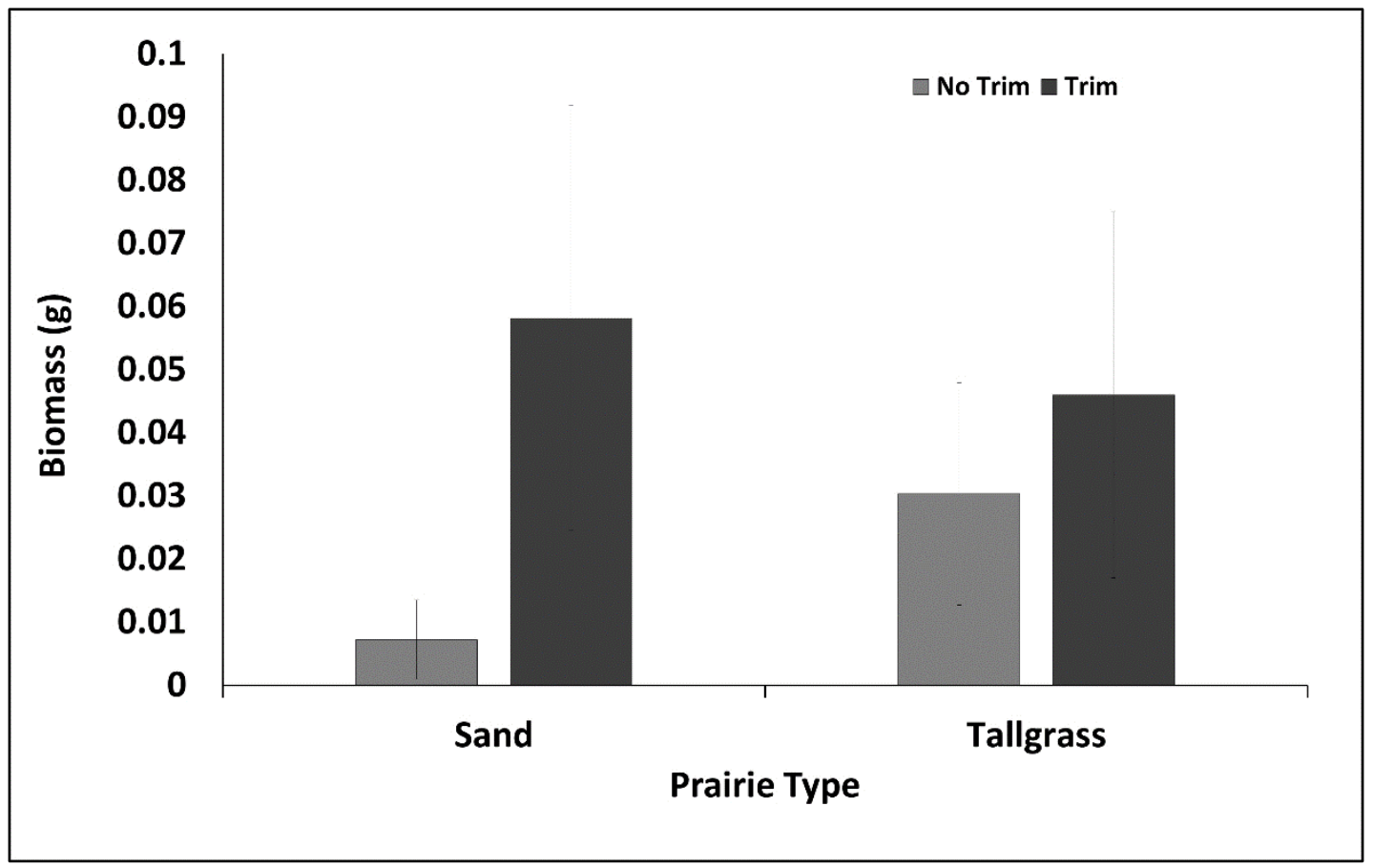

Figure 11. Field Fruit Biomass. The mean ( $\pm 1 \mathrm{SE}$ ) fruit biomass of $C$. fasciculata seed sources based on their trim treatment. The analysis is presented in table 9 . 


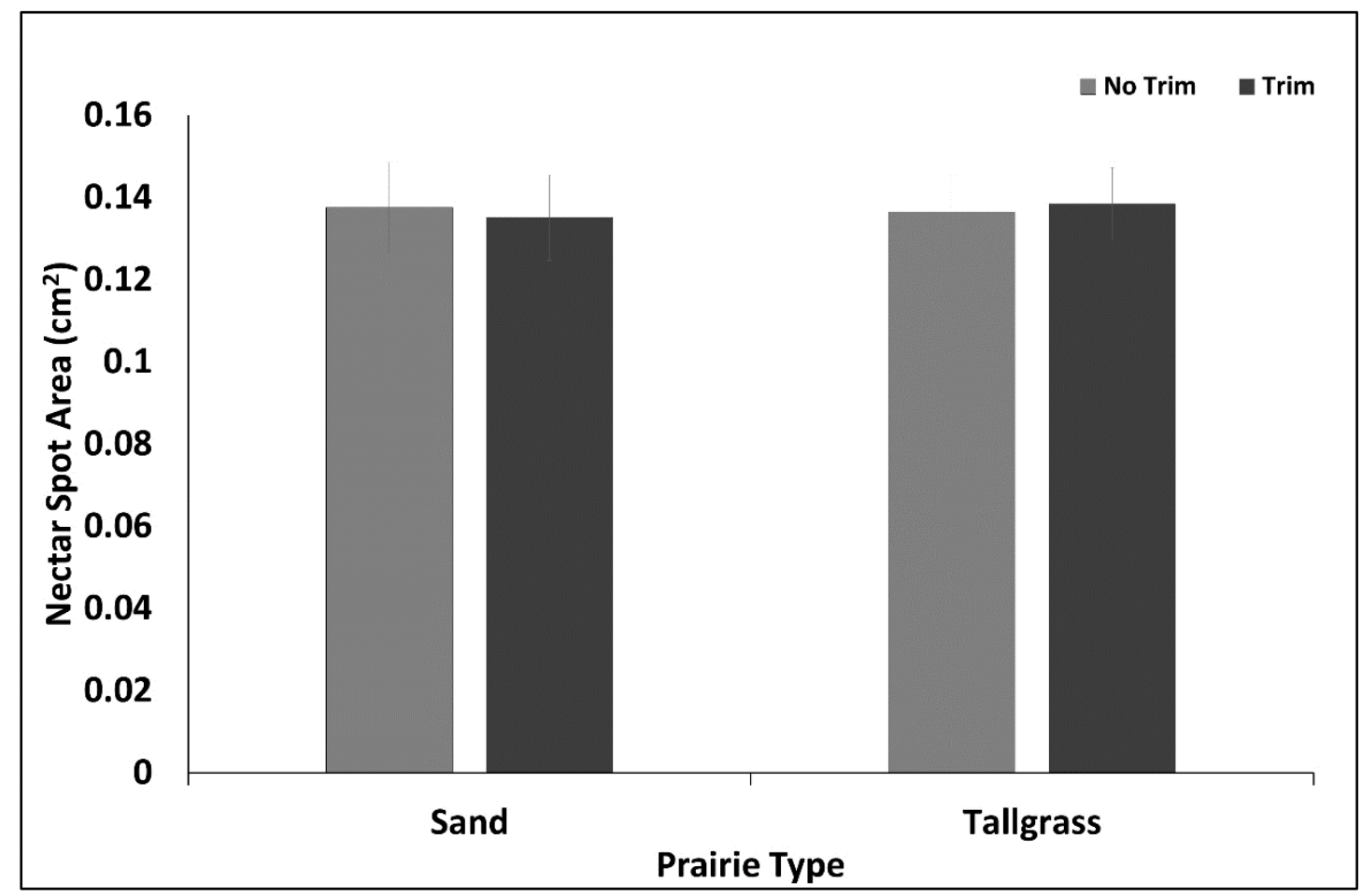

Figure 12. Nectar Production. The mean ( $\pm 1 \mathrm{SE})$ nectar production based on nectar spot area of C. fasciculata seed sources based on trimming treatment. The analysis is presented in table 10 . 


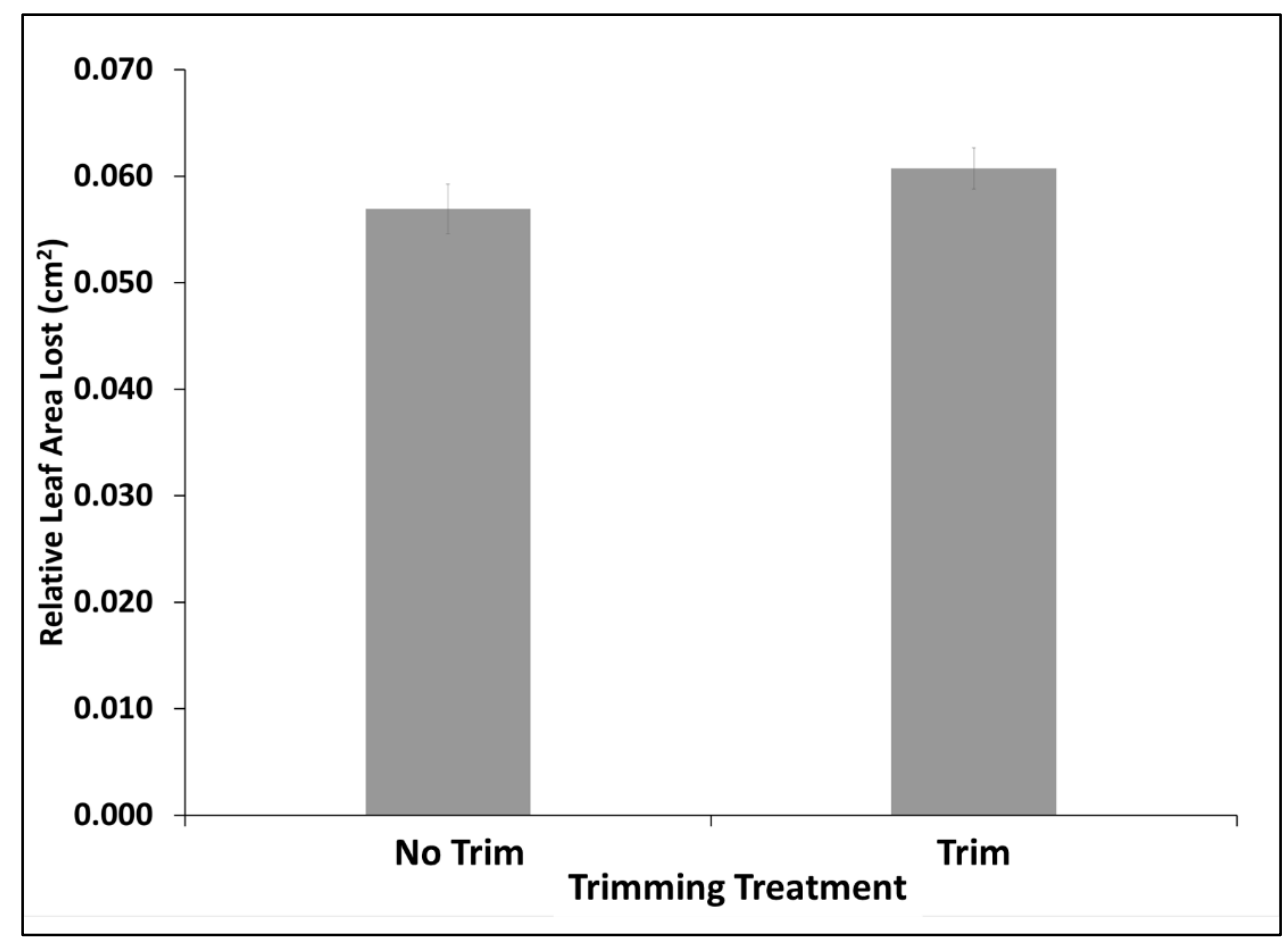

Figure 13. Relative Impact of Herbivory (July 24-25). The mean ( \pm 1 SE) relative impact of herbivory on $C$. fasciculata from July 24 to July 25 based on trimming treatment. Different letter denotes significantly different measurements $(\mathrm{P} \leq 0.05)$. The analysis is presented in table 11 . 


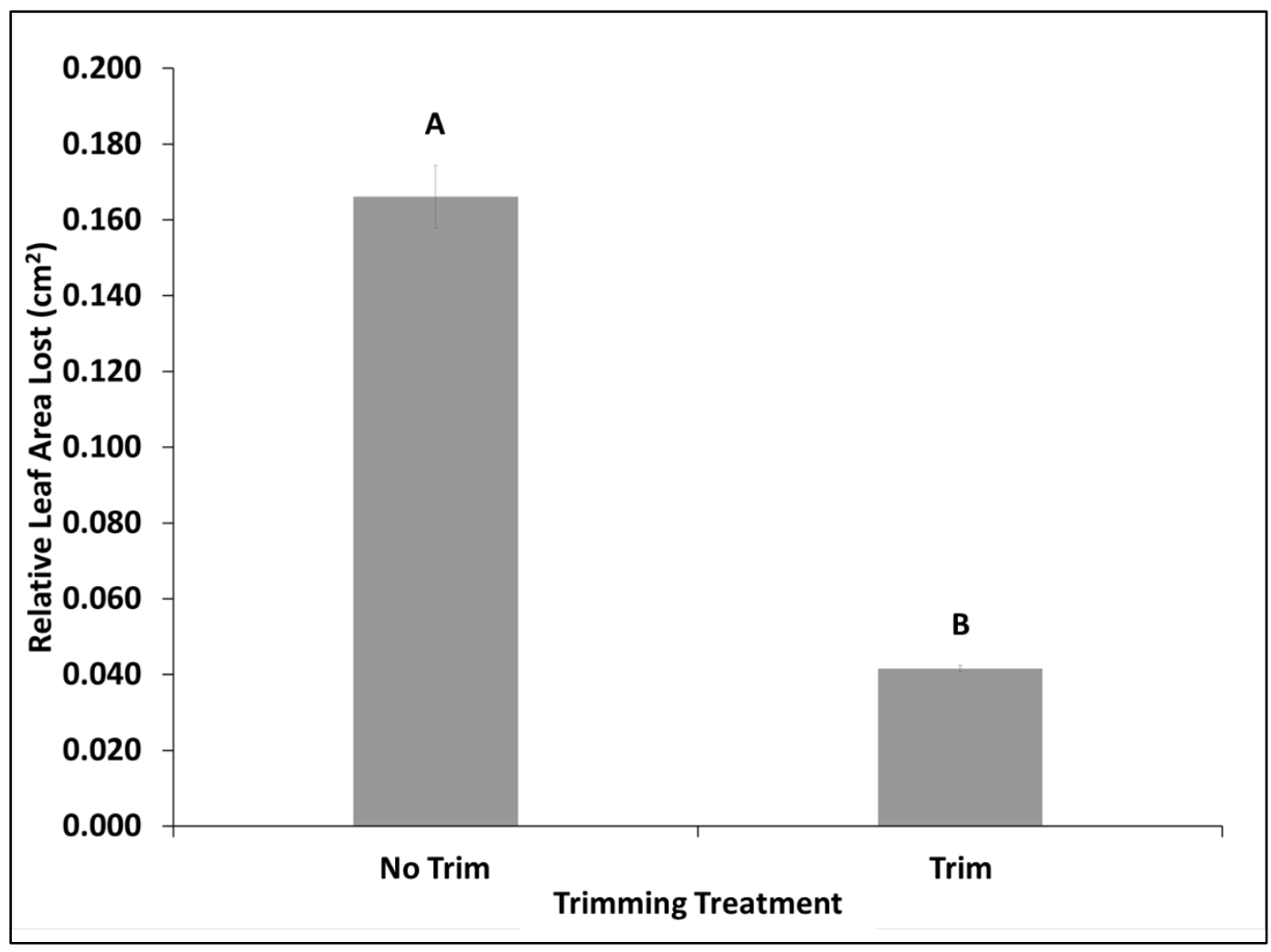

Figure 14. Relative Impact of Herbivory (August 30- September 1). The mean ( \pm 1 SE) relative impact of herbivory on C. fasciculata from August 30 to September 1. Different letter denotes significantly different measurements $(\mathrm{P} \leq 0.05)$. The analysis is presented in table 12 . 


\section{APPENDIX A: FIELD SITE SEED COLLECTION INFORMATION}

Appendix A. Listing of sites sampled for $C$. fasciculata seeds. Information of management styles of sites was determined through personal correspondence with site managers or from the Illinois Department of Natural Resource's website

(https://www.dnr.illinois.gov/Parks/Pages/default.aspx).

\begin{tabular}{|c|c|c|c|c|c|c|c|}
\hline Site Name & GPS & $\begin{array}{l}\text { Prairie } \\
\text { Type }\end{array}$ & Hectares & $\begin{array}{l}\text { Remnant } \\
\text { or Partly } \\
\text { Restored }\end{array}$ & $\begin{array}{l}\text { Soil } \\
\text { texture }\end{array}$ & $\begin{array}{l}\text { Soil Nutrients } \\
(\mathrm{N}, \mathrm{P}, \mathrm{K}, \mathrm{pH})\end{array}$ & Management \\
\hline $\begin{array}{l}\text { Weston Cemetery } \\
\text { Prairie Nature } \\
\text { Preserve }\end{array}$ & $\begin{array}{l}\text { N40.7467, } \\
\text { W-88.6145 }\end{array}$ & Tallgrass & 1.79 & Remnant & $\begin{array}{l}28 \% \text { sand, } \\
57 \% \text { silt, } \\
15 \% \text { clay }\end{array}$ & $\begin{array}{l}\mathrm{NO} 3-2.25 \mathrm{ppm} \\
\mathrm{K}-137 \mathrm{ppm} \\
\mathrm{P}-4 \mathrm{ppm}\end{array}$ & $\begin{array}{l}\text { - Wood species removal } \\
\text {-Prescribed burns (rotating } \\
\text { patches, 2-3 years) }\end{array}$ \\
\hline $\begin{array}{l}\text { Loda Cemetery Prairie } \\
\text { Nature Preserve }\end{array}$ & $\begin{array}{l}\text { N40.4453, } \\
\text { W-88.0973 }\end{array}$ & Tallgrass & 1.39 & Remnant & N/A & N/A & $\begin{array}{l}\text { - Wood species removal } \\
\text {-Prescribed burns (rotating } \\
\text { patches, 2-3 years) }\end{array}$ \\
\hline
\end{tabular}




\begin{tabular}{|c|c|c|c|c|c|c|c|}
\hline Site Name & GPS & $\begin{array}{l}\text { Prairie } \\
\text { Type }\end{array}$ & Hectares & $\begin{array}{l}\text { Remnant } \\
\text { or Partly } \\
\text { Restored }\end{array}$ & $\begin{array}{l}\text { Soil } \\
\text { texture }\end{array}$ & $\begin{array}{l}\text { Soil Nutrients } \\
(\mathbf{N}, \mathbf{P}, \mathbf{K}, \mathbf{p H})\end{array}$ & Management \\
\hline $\begin{array}{l}\text { Denby Prairie Nature } \\
\text { Preserve }\end{array}$ & $\begin{array}{l}\text { N39.2414, } \\
\text { W-89.9264 }\end{array}$ & Tallgrass & 2.54 & Remnant & $\begin{array}{l}14 \% \text { sand, } \\
64 \% \text { silt, } \\
22 \% \text { clay }\end{array}$ & $\begin{array}{l}\mathrm{NO} 3-1.43 \mathrm{ppm} \\
\mathrm{K}-78 \mathrm{ppm} \\
\mathrm{P}-10 \mathrm{ppm}\end{array}$ & $\begin{array}{l}\text { - Wood species removal } \\
\text {-Prescribed burns (rotating } \\
\text { patches, 2-3 years) } \\
\text {-Seeding of native species }\end{array}$ \\
\hline $\begin{array}{l}\text { Goose Lake Prairie } \\
\text { State Natural Area }\end{array}$ & $\begin{array}{l}\text { N41.3810, } \\
\text { W-89.691 }\end{array}$ & Tallgrass & 622.04 & $\begin{array}{l}\text { Partly } \\
\text { Restored }\end{array}$ & $\begin{array}{l}46 \% \text { sand, } \\
35 \% \text { silt, } \\
19 \% \text { clay }\end{array}$ & $\begin{array}{l}\text { NO3-1.79 ppm } \\
\mathrm{K}-34 \mathrm{ppm} \\
\mathrm{P}-3 \mathrm{ppm}\end{array}$ & $\begin{array}{l}\text { - Wood species removal } \\
\text {-Prescribed burns (rotating } \\
\text { patches, 2-3 years) }\end{array}$ \\
\hline $\begin{array}{l}\text { Henry Allan Gleason } \\
\text { State Natural Area }\end{array}$ & $\begin{array}{l}\text { N40.3796, } \\
\text { W-89.9292 }\end{array}$ & Sand & 44.51 & Remnant & $\begin{array}{l}94 \% \text { sand, } \\
1 \% \text { silt, } \\
5 \% \text { clay }\end{array}$ & $\begin{array}{l}\text { NO3 }-0.78 \mathrm{ppm} \\
\mathrm{K}-17 \mathrm{ppm} \\
\mathrm{P}-17 \mathrm{ppm}\end{array}$ & $\begin{array}{l}\text {-Prescribed burns (rotating } \\
\text { patches, 8-10 years) } \\
\text {-invasive species removal }\end{array}$ \\
\hline $\begin{array}{l}\text { Sand Ridge State } \\
\text { Forest }\end{array}$ & $\begin{array}{l}\text { N41.6133, } \\
\text { W-87.5541 }\end{array}$ & Sand & 0.96 & Remnant & $\begin{array}{l}94 \% \text { sand, } \\
1 \% \text { silt, } \\
5 \% \text { clay }\end{array}$ & $\begin{array}{l}\mathrm{NO}_{3}-0.64 \mathrm{ppm} \\
\mathrm{K}-20 \mathrm{ppm} \\
\mathrm{P}-33 \mathrm{ppm}\end{array}$ & $\begin{array}{l}\text {-Prescribed burns (rotating } \\
\text { patches, } 8-10 \text { years) } \\
\text {-invasive species removal }\end{array}$ \\
\hline
\end{tabular}




\begin{tabular}{|c|c|c|c|c|c|c|c|}
\hline Site Name & GPS & $\begin{array}{l}\text { Prairie } \\
\text { Type }\end{array}$ & Hectares & $\begin{array}{l}\text { Remnant } \\
\text { or Partly } \\
\text { Restored }\end{array}$ & $\begin{array}{l}\text { Soil } \\
\text { texture }\end{array}$ & $\begin{array}{l}\text { Soil Nutrients } \\
(\mathbf{N}, \mathbf{P}, \mathbf{K}, \mathbf{p H})\end{array}$ & Management \\
\hline $\begin{array}{l}\text { Sand Prairie Scrub } \\
\text { Oak State Nature } \\
\text { Preserve }\end{array}$ & $\begin{array}{l}\text { N40.1667, } \\
\text { W-90.0793 }\end{array}$ & Sand & 590.84 & $\begin{array}{l}\text { Partly } \\
\text { Restored }\end{array}$ & $\begin{array}{l}94 \% \text { sand, } \\
1 \% \text { silt, } \\
5 \% \text { clay }\end{array}$ & $\begin{array}{l}\mathrm{NO}_{3}-1.47 \mathrm{ppm} \\
\mathrm{K}-24 \mathrm{ppm} \\
\mathrm{P}-62 \mathrm{ppm}\end{array}$ & $\begin{array}{l}\text {-Prescribed burns (rotating } \\
\text { patches, } 8 \text {-10 years) } \\
\text {-invasive species removal }\end{array}$ \\
\hline $\begin{array}{l}\text { Green River State } \\
\text { Wildlife Area }\end{array}$ & $\begin{array}{l}\text { N41.6386, } \\
\text { W-89.5083 }\end{array}$ & Sand & 1038.07 & Remnant & $\begin{array}{l}69 \% \text { sand, } \\
27 \% \text { silt, } \\
4 \% \text { clay }\end{array}$ & $\begin{array}{l}\mathrm{NO}_{3}-0.15 \mathrm{ppm} \\
\mathrm{K}-58 \mathrm{ppm} \\
\mathrm{P}-12 \mathrm{ppm}\end{array}$ & $\begin{array}{l}\text {-Prescribed burns } \\
\text {-invasive species removal }\end{array}$ \\
\hline
\end{tabular}




\section{APPENDIX B: SPECIES COMPOSITION IN FIELD SITE SAMPLE PLOTS}

Appendix B. Listing of all species of plants found occurring with Chamaecrista fasciculata within sampled plots for all sites. Sampling plots $(1 \times 0.5 \mathrm{~m})$ were used in a previous study to assess the community of plants that $C$. fasciculata is subject to within tallgrass and sand prairies. 15 sample plots were setup in locations where $C$. fasciculata was present within each of the sites during the summers of 2014 and 2015.

\begin{tabular}{|c|c|c|c|c|c|c|c|c|c|}
\hline \multicolumn{2}{|l|}{ Species } & \multicolumn{4}{|c|}{ Tallgrass } & \multicolumn{4}{|l|}{ Sand } \\
\hline Scientific Name & Common Name & Weston & Denby & $\begin{array}{l}\text { Goose } \\
\text { Lake }\end{array}$ & Loda & $\begin{array}{l}\text { HA } \\
\text { Gleason }\end{array}$ & $\begin{array}{l}\text { Scrub } \\
\text { Oak }\end{array}$ & $\begin{array}{l}\text { Sand } \\
\text { Ridge }\end{array}$ & $\begin{array}{l}\text { Green } \\
\text { River }\end{array}$ \\
\hline \multicolumn{10}{|l|}{ Woody Species } \\
\hline Amorpha canescens & Lead Plant & $\mathrm{X}$ & & & & & & & \\
\hline Crataegus spa. & Hawthorn & $\mathrm{X}$ & $\mathrm{X}$ & & & & & & \\
\hline Quercus marilandica & Blackjack Oak & & & & & & & $\mathrm{X}$ & \\
\hline $\begin{array}{l}\text { Zanthoxylum } \\
\text { americanum }\end{array}$ & Prickly Ash & & $\mathrm{X}$ & & & & & & \\
\hline
\end{tabular}




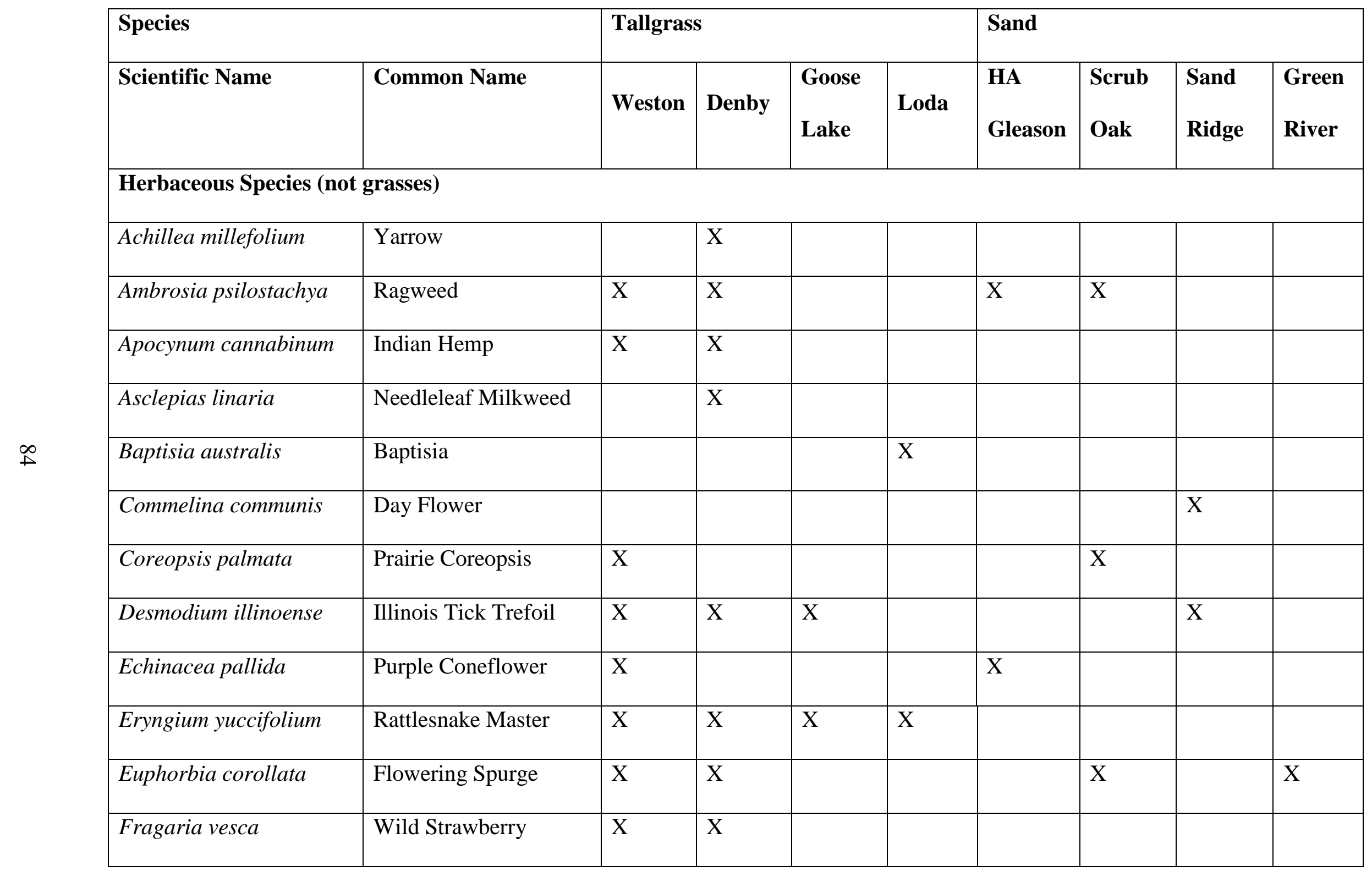




\begin{tabular}{|c|c|c|c|c|c|c|c|c|c|}
\hline \multicolumn{2}{|l|}{ Species } & \multicolumn{4}{|c|}{ Tallgrass } & \multicolumn{4}{|l|}{ Sand } \\
\hline Scientific Name & Common Name & Weston & Denby & $\begin{array}{l}\text { Goose } \\
\text { Lake }\end{array}$ & Loda & $\begin{array}{l}\text { HA } \\
\text { Gleason }\end{array}$ & $\begin{array}{l}\text { Scrub } \\
\text { Oak }\end{array}$ & $\begin{array}{l}\text { Sand } \\
\text { Ridge }\end{array}$ & $\begin{array}{l}\text { Green } \\
\text { River }\end{array}$ \\
\hline $\begin{array}{l}\text { Helianthus } \\
\text { grosseserratus }\end{array}$ & Sawtooth Sunflower & & & $\mathrm{X}$ & & & & & \\
\hline $\begin{array}{l}\text { Helianthus } \\
\text { grosseserratus }\end{array}$ & Sawtooth Sunflower & & & $\mathrm{X}$ & & & & & \\
\hline Liatris pycnostachya & Prairie Blazing Star & $\mathrm{X}$ & & & & & & & \\
\hline Lespedeza capitata & $\begin{array}{l}\text { Round Head Bush } \\
\text { Clover }\end{array}$ & & $\mathrm{X}$ & & & & & & \\
\hline Lobelia spicata & Pale Spike Lobelia & $\mathrm{X}$ & & & & & & & \\
\hline Lycopus americanus & American Bugleweed & & $\mathrm{X}$ & & & & & & \\
\hline Melilotus officinalis & Yellow Sweet Clover & $\mathrm{X}$ & $\mathrm{X}$ & & & & & & \\
\hline Monarda punctata & Bee Balm & $\mathrm{X}$ & & & & & & $\mathrm{X}$ & $\mathrm{X}$ \\
\hline Asclepias linaria & Needleleaf Milkweed & & $X$ & & & & & & \\
\hline Melilotus officinalis & Yellow Sweet Clover & $\mathrm{X}$ & $\mathrm{X}$ & & & & & & \\
\hline
\end{tabular}




\begin{tabular}{|c|c|c|c|c|c|c|c|c|c|}
\hline \multicolumn{2}{|l|}{ Species } & \multicolumn{4}{|c|}{ Tallgrass } & \multicolumn{4}{|l|}{ Sand } \\
\hline Scientific Name & Common Name & Weston & Denby & $\begin{array}{l}\text { Goose } \\
\text { Lake }\end{array}$ & Loda & $\begin{array}{l}\text { HA } \\
\text { Gleason }\end{array}$ & $\begin{array}{l}\text { Scrub } \\
\text { Oak }\end{array}$ & $\begin{array}{l}\text { Sand } \\
\text { Ridge }\end{array}$ & $\begin{array}{l}\text { Green } \\
\text { River }\end{array}$ \\
\hline Opuntia humifusa & Eastern Prickly Pear & & & & & $\mathrm{X}$ & $\mathrm{X}$ & $\mathrm{X}$ & \\
\hline Parthenium integrifolium & Wild Quinine & & & $\mathrm{X}$ & & & & & \\
\hline Physostegia virginiana & Obedient Plant & $\mathrm{X}$ & & & & & & & \\
\hline Ratibida pinnata & Yellow Coneflower & $\mathrm{X}$ & & $\mathrm{X}$ & & & & & \\
\hline Rosa arkansana & Prairie Rose & $\mathrm{X}$ & & $\mathrm{X}$ & & & & & \\
\hline Rubus idaeus & Raspberry & & $\mathrm{X}$ & $\mathrm{X}$ & $\mathrm{X}$ & & & & $\mathrm{X}$ \\
\hline Rudbeckia laciniata & Thimble Weed & $\mathrm{X}$ & & & & & & & \\
\hline Rudbeckia laciniata & Thimble Weed & $\mathrm{X}$ & & & & & & & \\
\hline Silphium laciniatum & Compass Plant & $\mathrm{X}$ & & & $\mathrm{X}$ & & & & $\mathrm{X}$ \\
\hline $\begin{array}{l}\text { Silphium } \\
\text { terebinthinaceum }\end{array}$ & Prairie Dock & & & & $\mathrm{X}$ & & & & $\mathrm{X}$ \\
\hline Solidago canadensis & Canadian Goldenrod & $\mathrm{X}$ & $\mathrm{X}$ & $\mathrm{X}$ & $\mathrm{X}$ & & & & $\mathrm{X}$ \\
\hline Solidago rigida & Stiff Goldenrod & $\mathrm{X}$ & & & & & & & \\
\hline
\end{tabular}




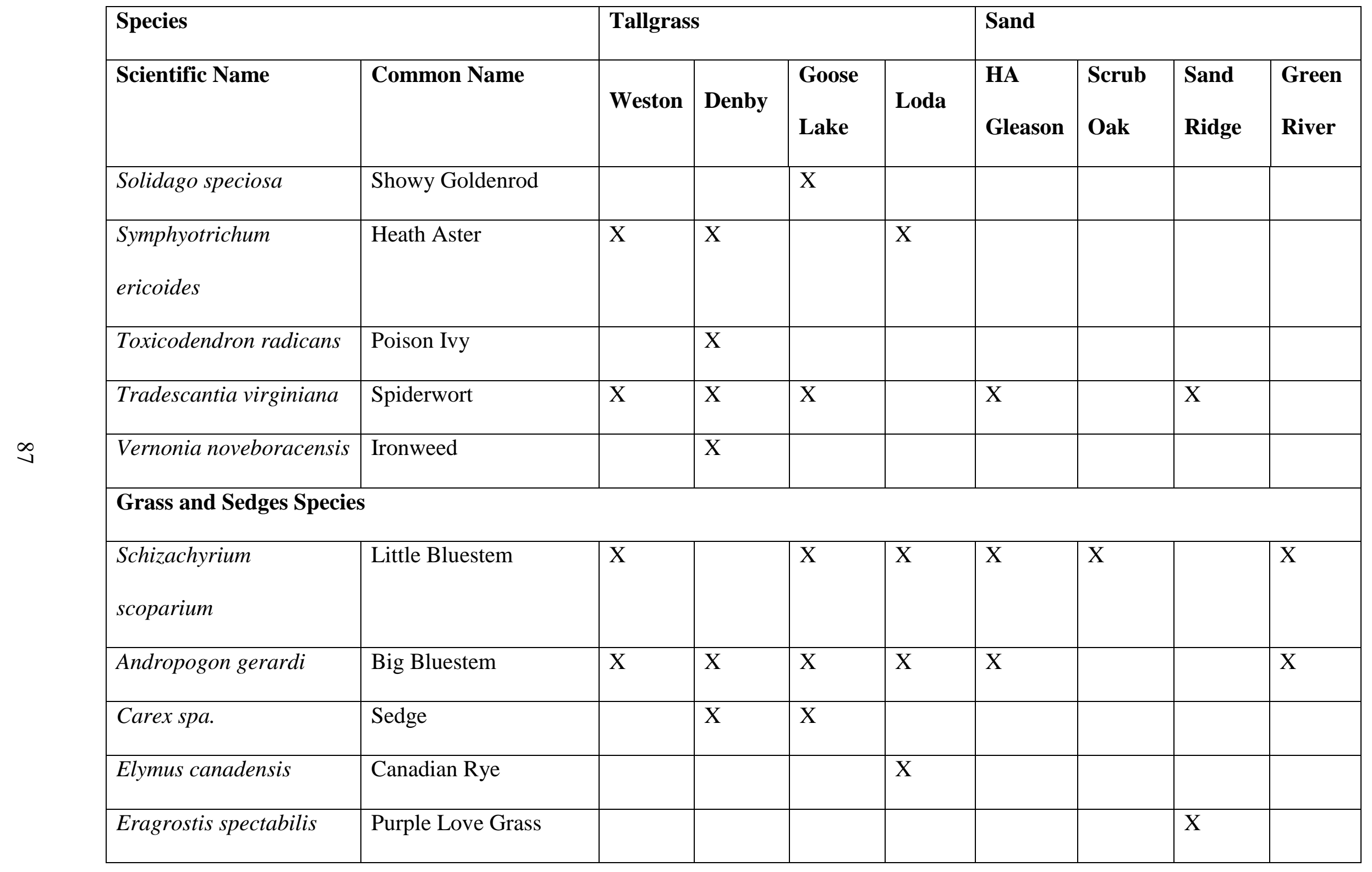




\begin{tabular}{|c|c|c|c|c|c|c|c|c|c|}
\hline \multicolumn{2}{|l|}{ Species } & \multicolumn{4}{|c|}{ Tallgrass } & \multicolumn{4}{|l|}{ Sand } \\
\hline Scientific Name & Common Name & Weston & Denby & $\begin{array}{l}\text { Goose } \\
\text { Lake }\end{array}$ & Loda & $\begin{array}{l}\text { HA } \\
\text { Gleason }\end{array}$ & $\begin{array}{l}\text { Scrub } \\
\text { Oak }\end{array}$ & $\begin{array}{l}\text { Sand } \\
\text { Ridge }\end{array}$ & $\begin{array}{l}\text { Green } \\
\text { River }\end{array}$ \\
\hline Hesperostipa spartea & Porcupine Grass & & & & & $\mathrm{X}$ & & $\mathrm{X}$ & \\
\hline Panicum virgatum & Switch Grass & & & $\mathrm{X}$ & & $\mathrm{X}$ & $\mathrm{X}$ & $\mathrm{X}$ & \\
\hline $\begin{array}{l}\text { Schizachyrium } \\
\text { scoparium }\end{array}$ & Little Bluestem & $\mathrm{X}$ & & $\mathrm{X}$ & $\mathrm{X}$ & $\mathrm{X}$ & $\mathrm{X}$ & & $\mathrm{X}$ \\
\hline Sorghastrum nutans & Indian Grass & & & & $\mathrm{X}$ & $\mathrm{X}$ & $\mathrm{X}$ & & $\mathrm{X}$ \\
\hline Sporobolus heterolepis & Prairie Dropseed & $\mathrm{X}$ & $\mathrm{X}$ & & & & & & \\
\hline
\end{tabular}




\section{APPENDIX C: ARTHROPOD SURVEY INFORMATION}

Appendix C. Arthropod species collected during two separate surveys on July 24, 2016 and August 16, 2016.

\begin{tabular}{|c|c|c|c|}
\hline Scientific Name & Common Name & Family & $\begin{array}{l}\text { Number } \\
\text { Captured }\end{array}$ \\
\hline Allograpta obliqua & Hover Fly & Syrphidae & 16 \\
\hline Anthophora walshii & Walsh's Digger & Apidae & 2 \\
\hline Aphaenogaster treatae & & Formicidae & 6 \\
\hline Apis mellifera & Honey Bee & Apidae & 11 \\
\hline Bombus impatiens & Eastern Bumblebee & Apidae & 9 \\
\hline $\begin{array}{l}\text { Coelocephalapion } \\
\text { decoloratum }\end{array}$ & & Brentidae & 4 \\
\hline Colias eurytheme & Orange Sulphur & Pieridae & 7 \\
\hline Colias philodice & Clouded Sulfur & Pieridae & 6 \\
\hline Crematogaster lineolata & & Formicidae & 3 \\
\hline Eurema lisa & Little Sulphur & Pieridae & 3 \\
\hline Formicia montana & Prairie Mound Ant & Formicidae & 1 \\
\hline Helophilus fasciatus & Syrphid Fly & Syrphidae & 12 \\
\hline Kissingeria amaurum & & Brentiae & 2 \\
\hline Lasius neoniger & Turfgrass Ant & Formicidae & 1 \\
\hline Monomorium minimum & Little Black Ant & Formicidiae & 12 \\
\hline
\end{tabular}




\begin{tabular}{|l|l|l|l|}
\hline Scientific Name & Common Name & Family & $\begin{array}{l}\text { Number } \\
\text { Captured }\end{array}$ \\
\hline Nylanderia parvula & & Formicidae & 2 \\
\hline Phoebis sennae & Cloudless Sulphur & Pieridae & 6 \\
\hline Phoetaliotes nebrascensis & Large Headed & Acrididae & 11 \\
\hline Rhytidolomia belfragii & Stink Bug & Pentatomidae & 7 \\
\hline Svastra atripes & Long Horn Bee & Apidae & 1 \\
\hline Tapinoma sessile & Sugar Ant & Formicidae & 3 \\
\hline Temnothorax ambiguus & & Formicidae & 1 \\
\hline
\end{tabular}

